\title{
DOES IT MATTER HOW CENTRAL BANKS ACCUMULATE RESERVES? EVIDENCE FROM SOVEREIGN SPREADS
}

\author{
César Sosa-Padilla \\ Federico Sturzenegger \\ Working Paper 28973 \\ http://www.nber.org/papers/w28973 \\ NATIONAL BUREAU OF ECONOMIC RESEARCH \\ 1050 Massachusetts Avenue \\ Cambridge, MA 02138 \\ June 2021, Revised November 2022
}

We thank Santiago Cesteros, Nicolás Der Meguerditchian, Sebastián Eintoss and Santiago Mosquera for able research assistance, Juan Francisco Gomez, Christoph Grosse-Steffen, Alejandro Izquierdo, and Eduardo Levy-Yeyati for sharing data with us, and Walter Sosa Escudero and Enrique Szewach for useful suggestions. The views expressed herein are those of the authors and do not necessarily reflect the views of the National Bureau of Economic Research.

NBER working papers are circulated for discussion and comment purposes. They have not been peer-reviewed or been subject to the review by the NBER Board of Directors that accompanies official NBER publications.

(C) 2021 by César Sosa-Padilla and Federico Sturzenegger. All rights reserved. Short sections of text, not to exceed two paragraphs, may be quoted without explicit permission provided that full credit, including $\odot$ notice, is given to the source. 
Does It Matter How Central Banks Accumulate Reserves? Evidence from Sovereign Spreads César Sosa-Padilla and Federico Sturzenegger

NBER Working Paper No. 28973

June 2021, Revised November 2022

JEL No. F32,F34,F41

\begin{abstract}
There has been substantial research on the benefits of accumulating foreign reserves, but less on the relative merits of how these reserves are accumulated. In this paper we explore whether the form of accumulation affects country risk. We first present a model of endogenous sovereign debt defaults, where we show that reserve accumulation through the issuance of debt contingent on local output reduces spreads in a way that reserve accumulation with foreign borrowing does not. We confirm this model prediction when taking the theory to the data. These results suggest that attention should be placed on the way reserves are accumulated, a distinction that has important practical implications. In particular, our results call into question the benefits of programs of reserves strengthening through external debt such as those typically implemented by multilateral organizations.
\end{abstract}

César Sosa-Padilla

Department of Economics

University of Notre Dame

3060 Jenkins Nanovic Hall

Notre Dame, IN 46556

and NBER

csosapad@nd.edu

Federico Sturzenegger

Universidad de San Andres

Vito Dumas 284

Victoria Buenos Aires

B1644BID

Argentina

fsturzenegger@udesa.edu.ar 


\section{Introduction}

There is an extensive literature on the benefits and costs of holding foreign reserves. The benefits associated to reserves can be broadly related to three basic attributes: the role of reserves as a source of liquidity, their role as a hedging mechanism, and as a way to modify the real exchange rate in what has been called the "mercantilistic" motive. The costs of reserves are associated to the financing costs of such reserves: the foreign interest rate if the reserves are borrowed, the domestic interest rate premia if purchased with domestic assets, or their impact on inflation if purchased through unsterilized interventions.

One important motivation for reserves has been that of providing a liquidity reservoir for times of need in which reserves can be used to smooth balance of payments disruptions. Initially the focus was mostly related to disruptions in trade flows (reserves were aimed at covering a given number of months of imports) but more recently have focused on capital flows. This second view was popularized in the so called Greenspan-Guidotti rule, a rule of thumb by which central banks should hold reserves equivalent to the government's short term liabilities (Greenspan, 1999). Jeanne and Ranciere (2011) formalized this idea in a framework that added both a negative output effect of capital flow reversals as well as a positive effect of reserve accumulation on spreads. They find that a model with these ingredients delivers levels of reserves consistent with those observed in most countries. After the great financial crisis many studies showed that reserves allowed countries to face the financial crisis with lower output costs (e.g., Dominguez et al., 2012, and Bussière et al., 2015). Levy-Yeyati (2008) documents the impact of reserves on spreads suggested in Jeanne and Ranciere (2011). As a broad summary of these findings, the IMF in 2011 (see IMF, 2011) proposed a practitioner's guide to estimate optimal reserves where exposure to financial flow reversals (measured as the ratio of short term debt to M2) and trade flows were the main ingredients.

In recent years, this approach has been complemented by the view that reserves may actually not only provide liquidity in times of need, but that they may actually change the equilibrium of the economy. In this line, a recent literature on sovereign debt and reserve accumulation shows how larger holdings of international reserves change the borrowing terms faced by emerging countries and (under certain conditions) reduce equilibrium spreads (see Alfaro and Kanczuk, 2009, Bianchi et al., 2018, and Bianchi and Sosa-Padilla, 2020). Relatedly, the role of reserves

for lender-of-last-resort support are discussed in Bocola and Lorenzoni (2017) and Céspedes and Chang (2019). 
The hedging role of reserves was originally discussed in relation to the currency composition of reserves (see Dellas and Yoo, 1991), but was taken a step further by Caballero and Panageas (2003). Their idea is that the government could aim at improving its income at times of distress by investing reserves in instruments that correlated negatively with its own shocks. Alfaro and Kanczuk (2019) study the role of domestic liabilities as a way of providing this hedge in a model with reserve accumulation and sovereign default. They find that countries issue domestic debt and accumulate reserves to hedge against negative shocks. Bianchi and Sosa-Padilla (2020) highlight a macro-stabilization hedging role for reserves in a model with default risk and nominal rigidities. Since sovereign risk is countercyclical, low income states will simultaneously show high interest rates and slack in the labor market. Therefore, having reserves reduces the need to rollover debt maturing at high interest rates and frees up resources to stabilize macro fluctuations (i.e., reduce the slack in the labor market). Bianchi and Sosa-Padilla (2020) label this effect the "macro-stabilization hedging" benefit of issuing debt to buy reserves. ${ }^{1}$ A practitioner's guide to implement these ideas is discussed in Sturzenegger (2019), and Orazi et al. (2020). In particular Orazi et al. (2020) develop a model of asset allocation for foreign reserves that is chosen in order to correlate negatively with the shocks faced by the economy.

Finally, the mercantilistic approach was an attempt to explain the policy of central banks aimed at avoiding large exchange rate appreciations, a motivation that became prominent during the reserves buildups of the 2000s, and particularly by the presumption that China was accumulating reserves to fight an appreciation of its currency. It was initially suggested in Aizenman and Riera-Crichton (2008), though Aizenman and Lee (2007) argue that on a quantitative dimension, the role of the mercantilist view is dwarfed by other determinants, particularly liquidity.

Other theories highlight the interaction between growth externalities and financial frictions as a rationale for reserve accumulation (Benigno et al., 2021), and as a macroprudential policy tool (Arce et al., 2019).

These different motivations for holding external reserves, in turn, have led to alternative measures of the benefits of these reserves. Rodrik and Velasco (1999) and Rodrik (2006) provide an assessment of the benefits of reserves in terms of avoiding financial crises. They estimate a $10 \%$ reduction in the probability of a crisis, which, combined with a $10 \%$ drop in output in such events, entails a benefit equivalent to $1 \%$ of GDP. ${ }^{2}$ Rodrik (2006) suggests that such a benefit bodes reasonably well with the spread differentials that countries pay to hold reserves.

\footnotetext{
${ }^{1}$ In their model there is also a traditional 'liquidity' role for reserves.

${ }^{2} \mathrm{An}$ independent estimation of the effect of reserves on the probability of a sudden stop is provided by Calvo et al. (2013).
} 
Levy-Yeyati (2008) argues that, because of the positive effect of reserves on spreads, the cost of holding reserves has been overestimated.

In this literature, two issues have captured less attention than they deserve. First, that it is typically assumed that the central bank's and government's balance sheet are one and the same, even when debt is typically issued by the government and does not constitute central bank debt. The issue of who accumulates reserves may be a relevant issue, particularly if the central bank is independent, but has been largely ignored. ${ }^{3}$

A second issue, which will be the main point discussed here, relates to the way the reserves buildup is financed. In fact, there are three main ways to purchase reserves: by unsterilized purchases, by issuing foreign currency denominated debt, and by issuing debt which may be contingent to local output. Below we will argue that domestic currency denominated debt belongs to the latter category.

It is easy to argue that the way reserves are financed should have a bearing on the effect of reserves. For example, accumulating reserves with foreign currency denominated liabilities provides liquidity but no hedge, where we refer to hedging as a way of generating positive valuation effects (in Alfaro and Kanczuk, 2019's terminology) in times of distress. This differs from the effects of accumulating reserves with state contingent debt which provides both liquidity and hedging benefits.

Accumulating reserves with liabilities entails an interest rate cost known as carry which is another channel through which the mechanism used for accumulation matters. If liabilities are issued in foreign currency the carry comprises the country risk and a time premia, as debt issued to finance reserves typically has a longer maturity than the assets where those resources are parked. This interest rate premia can be thought as the "insurance" cost that pays off in terms of benefits of consumption smoothing when reserves are used, a benefit that, as was mentioned, Jeanne and Ranciere (2011) show justifies the levels of reserves seen in the data.

The same calculation holds when accumulating reserves with state contingent debt, except that the carry needs to compensate for the risk properties of this debt, which provides a higher level of insurance in bad times. This higher level of protection implies that the "insurance" premia is typically (but not necessarily) larger.

Given the practical relevance of these effects it is somewhat surprising that there is a relatively scant literature evaluating the implications of how reserve accumulation is done. This paper will

\footnotetext{
${ }^{3}$ See Samano (2021) for a recent study of reserve accumulation and default without perfect coordination between the central bank and the government.
} 
focus on how sovereign spreads are affected by the way reserves are accumulated. We will show, both theoretically and empirically, that the financing mechanism does matter for the level of spreads.

At the theoretical level, our paper builds on Alfaro and Kanczuk (2019) who provide a model where reserves can be accumulated with debt issued in terms of tradables or non-tradables. They assume that both debt and reserves are short-term and so the optimal portfolio is particularly sensitive to roll-over risk. This, in turn, delivers similar levels of reserves and debt, something at odds with the data. While their model underscores that the way reserves are accumulated is a key element in evaluating their value, we generalize their model assuming that 'domestic debt' is a financial instrument that pays coupons contingent on the realization of the domestic income, as opposed to modelling debt issued in non-tradable units. ${ }^{4}$ Moreover, following Bianchi, Hatchondo and Martinez (2018), we use a model with long-term debt and short-term reserves (a better description of the assets used by the governments and central banks), and show that in this case the resulting equilibrium portfolios are closer to the data.

At an empirical level, Levy-Yeyati and Gómez (2020) somewhat address the issue, but only to assess the benefits of leaning-against-the-wind policies. They show that central banks accumulating reserves financed with domestic currency may experience valuations gains if they follow a policy of purchasing to avoid large appreciations while selling at moments of distress. But they do not take the following step to see if this, which reinforces the hedging properties of reserves, leads to lower spreads. We show that it does.

The paper is organized as follows. The next subsection describes a specific case that motivates why this issue is important for policy. In section 2 we present a theoretical framework allowing for alternative ways of accumulating reserves and trace the effect of each one of them on sovereign spreads. A testable implication of our theory is that, for a given level of debt, financing reserve accumulation with contingent debt (in particular, using an instrument indexed to domestic income) allows the country to pay lower spreads than it would otherwise (i.e., had it used non-state contingent debt instead), a channel that becomes more important the larger the macro-vulnerabilities of the country. Section 3 takes the model to the data. We confirm the theoretical predictions both using cross country regressions as well as looking at specific exogenous events. Our results indicate that the source of financing matters. Accumulating reserves with domestic liabilities is beneficial in mitigating country risk, whereas accumulating reserves with

\footnotetext{
${ }^{4}$ Our modelling of state-contingent debt follows the work of Durdu (2009), Bertinatto et al. (2017) and Roch and Roldan (2021). In particular, our model is similar to the one in Roch and Roldan (2021) except that we allow for reserve accumulation and do not consider the case of robust foreign lenders.
} 
foreign liabilities provide no visible benefit. Section 4 provides two robustness checks. We first allow for private sector production and borrowing. We show that the inclusion of the private sector does not affect the results which is robust to whether the private sector uses contingent or non contingent debt. We then test whether our result stand for other measures of crisis risk such as Goldman Sachs' financial conditions index. We show the results also hold for this broader measure. Finally, section 5 concludes and provides a discussion for future work in this area.

\subsection{A Personal Motivation}

The previous debate has practical implications for central banking, as one of us verified between 2015 and 2018 when serving as Governor of the Central Bank of Argentina. At the end of the year 2015 Argentina had negative net reserves in its central bank, strict exchange rate controls, and a black market premium for US dollars larger than $70 \%$ (the official rate was at 9 pesos per dollar while the black market rate stood at around 16). In a single move capital controls were removed, exchange rate markets unified, and the exchange rate was allowed to float. Immediately after lifting restrictions, the exchange rate settled at around 13 pesos per dollar (basically the mid point between the two previous exchange rates) and the peso floated for the following two years with minimal central bank intervention.

From this starting point, and considering that reserves were nonexistent, the central bank started an aggressive program of reserves buildup. In the following two years the Central Bank of Argentina purchased about 40 billion dollars, roughly 8\% of GDP. However, purchasing this amount of reserves was not cost-free. In fact, the reserve purchases were sterilized with short term central bank paper denominated in domestic currency. Thus, in 2016 and 2017, as reserves piled up so did the amount of central bank liabilities. Figure 1 shows the evolution of these liabilities, of net reserves, as well as the difference between the two (these can be called "unbacked liabilities").

As can be seen, the process entailed a concomitant increase in net reserves and central bank liabilities while "unbacked" liabilities remained roughly constant throughout 2016 and 2017. The process of reserve accumulation peaked by the end of 2017 when net reserves had increased from negative to close to 40bn dollars, while central bank liabilities had grown from around 25bn to around 75 bn dollars. 


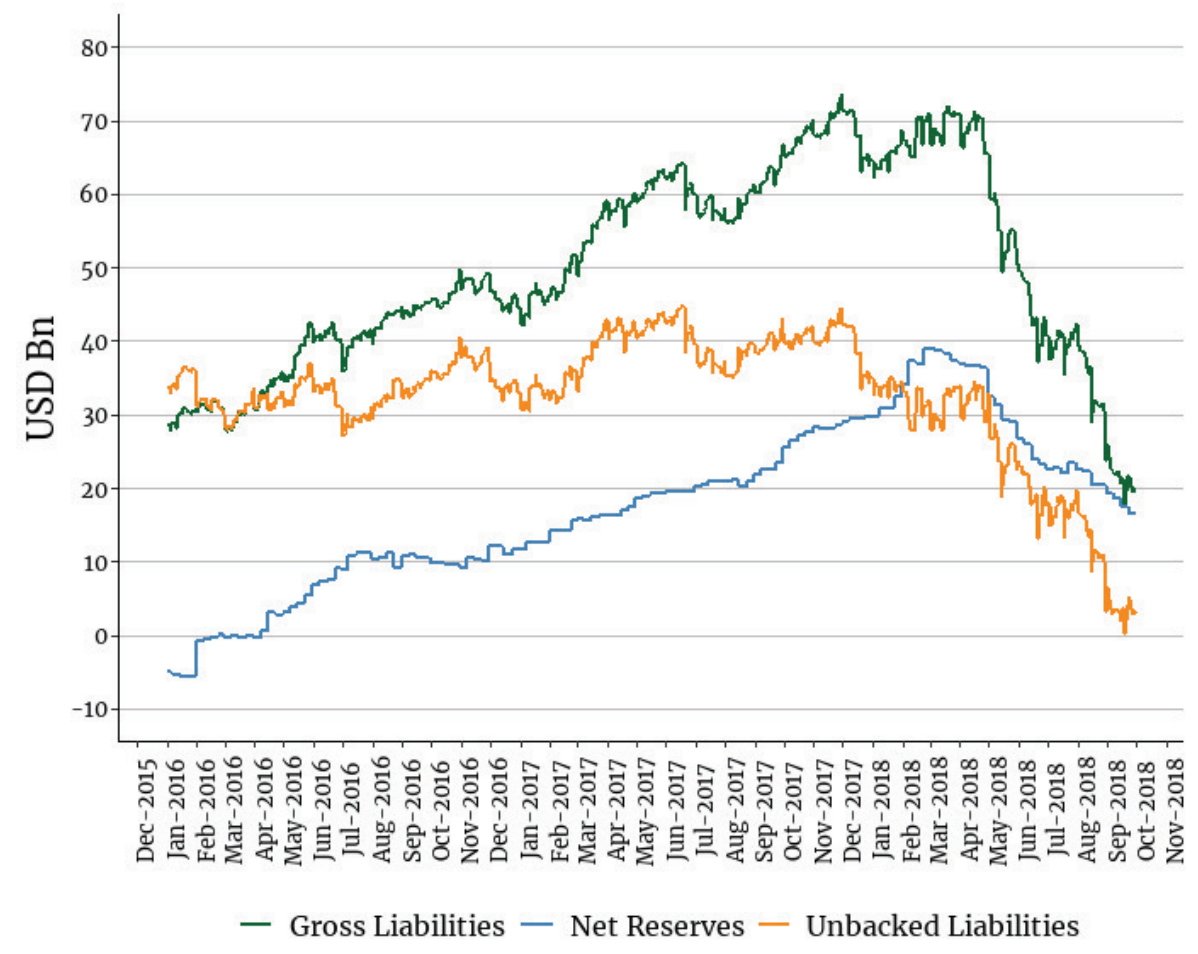

Figure 1: Central Bank of Argentina's Net Liabilities

In early 2018 Argentina was hit by a sudden stop. ${ }^{5}$ The central bank reacted by selling reserves against short term liabilities, undoing the reserve accumulation of the previous two years though allowing the exchange rate to slide. As the exchange rate depreciated, the central bank experienced a significant improvement in its balance sheet since the dollar value of its local currency denominated liabilities virtually collapsed. Sturzenegger (2020) shows that the net worth of the central bank improved in 2018 by around 38 billion dollars, a valuation gain of close to $8 \%$ of GDP. In this episode, issuing domestic debt to purchase reserves provided a large hedge in the face of the sudden stop.

This historical case illustrates some of the issues discussed in the previous section regarding the role of reserves and the way in which they are financed. In this case reserves were financed by issuing domestic currency denominated liabilities which ended up providing a sizable hedge under distress (when their dollar value virtually melted down). Had these reserves been purchased with

\footnotetext{
${ }^{5}$ The sudden stop was the result of a series of macroeconomic mishaps. The government elected in late 2015 had maintained a large budget deficit that the market had happily financed, even at decreasing spreads. The government then won the midterm elections of 2017, as output was growing and inflation coming down. With the benefit of hindsight, it is easy to see that the markets considered the electoral win as a deadline for starting fiscal consolidation while the government considered the win as an endorsement of its gradualistic approach to fiscal correction. As a result, the government pushed a tax reform that decreased taxes and increased the inflation target to push the central bank into a less tighter mode. Both changes triggered market skepticism which shortly after became a sudden stop. See Sturzenegger (2020) for a fuller description of these events.
} 
foreign debt such reduction would have not occurred.

In the next section we model precisely this effect, the use of state contingent debt to accumulate reserves allowing a valuation gain in times of distress. Only then we turn to testing this implication in a broad data set of emerging economies.

\section{Model}

In this section we present a dynamic equilibrium model of a small-open economy with long-term defaultable debt and short-term reserves, as in Bianchi et al. (2018). However, we allow here for two alternative debt instruments: (standard) non-contingent and contingent claims. This will allow to compare the effects of the different financing mechanism.

\section{$2.1 \quad$ Environment}

Preferences and income process. The representative agent in the borrowing economy has preferences given by

$$
\mathbb{E}_{t} \sum_{j=t}^{\infty} \beta^{j-t} u\left(c_{j}\right),
$$

where $u(c)=\frac{c^{1-\gamma}-1}{1-\gamma}$ is the flow utility function (with $\gamma \neq 1$ ), $\mathbb{E}$ denotes the expectation operator, $\beta$ denotes the subjective discount factor, and $c_{t}$ represents consumption of private agents. The utility function is strictly increasing and concave. The government cannot commit to future (default and borrowing) decisions. ${ }^{6}$

The economy's endowment of the single tradable good is denoted by $y \in Y \subset \mathbb{R}_{++}$. This endowment is assumed to follow a stationary first-order Markov process given by

$$
\log \left(y_{t}\right)=(1-\rho) \mu_{y}+\rho \log \left(y_{t-1}\right)+\varepsilon_{t}
$$

with $|\rho|<1$ and $\varepsilon \stackrel{i i d}{\sim} N\left(0, \sigma_{\varepsilon}^{2}\right)$.

Asset space. The small open economy also borrows from a large pool of international investors by issuing long-duration (potentially) indexed bonds. A bond issued in period $t$ promises an

\footnotetext{
${ }^{6}$ Thus, one may interpret this environment as a game in which the government making decisions in period $t$ is a player who takes as given the (default and borrowing) strategies of other players (governments) who will decide after $t$.
} 
infinite stream of coupons, whose mean decreases at a constant rate $\delta^{7}$ In particular, a bond issued issued in period $t$ promises to pay $\kappa\left[1+\phi\left(y_{t+j}-\bar{y}\right)\right](1-\delta)^{j-1}$ units of the tradable good in period $t+j$, for all $j \geq 1 .^{8}$ Parameter $\kappa$ controls the average size of coupon payments, the mean income level is denoted with $\bar{y}$, and $\phi \geq 0$ is a parameter that captures the "degree of indexation" of the contingent bond. ${ }^{9}$ This way of modelling the state-contingent coupon payments is similar to the linear-indexation in Roch and Roldan (2021). ${ }^{10}$

Hence, debt dynamics can be represented as follows:

$$
b_{t+1}=(1-\delta) b_{t}+i_{t}
$$

where $b_{t}$ is the number of coupons due at the beginning of period $t$ and $i_{t}$ is the number of longterm bonds issued in period $t$. The advantage of this payment structure is that it enables us to condense all future payment obligations derived from past debt issuances into a one-dimensional state variable: the payment obligations that mature in the current period.

The economy can also save, using one-period risk-free assets, $a$ (which we call reserves). Reserves trade at a price of $q_{a}$ and pay one unit of the tradable endowment in the next period.

Foreign lenders. Bonds are priced in a competitive market inhabited by a large number of identical lenders. To capture global factors that are exogenous to domestic fundamentals, we introduce risk premium shocks. These shocks are not critical for the mechanism but enrich the analysis and are in line with a large empirical literature on the role of global shocks in driving spreads and credit flows. ${ }^{11}$

Foreign lenders price the payoffs of bonds using the following stochastic discount factor, following Vasicek (1977):

$$
m_{t, t+1}=e^{-r-\omega_{t}\left(\varepsilon_{t+1}+0.5 \omega_{t} \sigma_{\varepsilon}^{2}\right)}, \quad \text { with } \quad \omega_{t} \geq 0 .
$$

\footnotetext{
${ }^{7}$ Arellano and Ramanarayanan (2012) and Hatchondo et al. (2016) allow the government to issue both shortterm and long-term debt, and study optimal maturity. Hatchondo et al. (2014) allow the government to issue both defaultable and non-defaultable debt.

${ }^{8}$ Formally, in order to rule out negative payments, we impose a coupon structure that is: $\max \left\{\kappa\left[1+\phi\left(y_{t+j}-\bar{y}\right)\right](1-\delta)^{j-1}, 0\right\}$. However, the coupon payments are always positive in our simulations.

${ }^{9}$ If parameter $\phi$ is equal to zero then the coupon payments are as in Hatchondo and Martinez (2009) and our model collapses to the one in Bianchi et al. (2018).

${ }^{10}$ Bertinatto et al. (2017) and Hatchondo and Martinez (2012) are early references to works on sovereign default with indexed contracts. Roch and Roldan (2021) study the benefits (and costs) of using indexed sovereign bonds when the economy faces robust lenders. Durdu (2009) studies indexed bonds in a small open economy with financial frictions (abstracting from sovereign default).

${ }^{11}$ See for example Longstaff et al. (2011); Forbes and Warnock (2012); Uribe and Yue (2006), Rey (2013); Johri, Khan and Sosa-Padilla (2020).
} 
Here, $r$ is the international risk-free rate, and $\omega_{t} \geq 0$ is a stochastic parameter governing the risk premium shock. Notice that (2) implies that bond payoffs are more valuable for investors when the small open economy faces a negative shock, capturing a positive degree of correlation between the small open economy and the lenders' income process. To the extent that the government is more likely to default when there are negative shocks to the tradable endowment $(\varepsilon)$, this implies that lenders demand a positive risk premium to be willing to invest in government bonds.

The risk premium shock $\omega$ follows a two-state Markov switching regime with values $\left\{\omega_{L}, \omega_{H}\right\}$ and transition probabilities $\left\{\pi_{L H}, \pi_{H L}\right\}$. In the "risk-neutral regime," we assume that $\omega=\omega_{L}=0$ so that the stochastic discount factor reduces to $m_{t, t+1}=e^{-r}$, eliminating any risk premia. In the "risk premia regime," $\omega=\omega_{H}>0$, and lenders require a risk premia to invest in government bonds. The value of $\omega$ can be seen as capturing how correlated the small open economy is with the lenders' income process or, alternatively, the degree of diversification in foreign lenders' portfolios. Therefore, a higher $\omega$ is associated with stronger risk premium shocks.

The standard asset pricing condition for bonds is therefore

$$
q_{t}=\mathbb{E}_{t}\left\{m_{t, t+1}\left(1-\hat{d}_{t+1}\right)\left[\kappa\left(1+\phi\left(y_{t+1}-\bar{y}\right)\right)+(1-\delta) q_{t+1}\right]\right\}
$$

where $\hat{d}_{t+1}$ is the equilibrium default decision in $t+1$. Notice that assuming that these investors also price the risk-free asset gives us that the price of reserves is $q_{a}=e^{-r}$, a result that follows from the log-normal structure of the lender's stochastic discount factor.

Defaults. When the government defaults, it does so on all current and future debt obligations. This is a standard assumption in the literature. ${ }^{12}$

Upon default, the government retains control of its reserves and access to savings but cannot borrow in the default period. A default entails a utility loss $\psi_{d}(y)$, which depends on the realization of the endowment. We think of this utility loss as capturing various default costs related to reputation, sanctions, or misallocation of resources; we do not model these explicitly. ${ }^{13}$ We abstract from financial exclusion as an additional source of default penalty. That is, the

\footnotetext{
${ }^{12}$ Sovereign debt contracts often contain an acceleration clause and a cross-default clause. The first clause allows creditors to call the debt they hold in case the government defaults on a payment. The cross-default clause states that a default in any government obligation constitutes a default in the contract containing that clause. These clauses imply that after a default event, future debt obligations become current.

${ }^{13} \mathrm{An}$ alternative assumption in the literature specifies an exogenous cost of default in terms of output. Assuming $\log$ utility and that output losses from default are proportional to consumption in default, the losses from default are identical for the output and utility cost specifications. See Sturzenegger (2004), Sturzenegger and Zettelmeyer (2006), and Sosa-Padilla (2018) for related work on the cost of sovereign defaults.
} 
government can once again borrow from international markets in the period following a default.

Timing. The timing of events within each period is as follows. First, the government learns the economy's income and the realization of the global risk premium shock. After that, the government chooses whether to default on its debt. Before the period ends, the government may change its debt and reserves positions, subject to the constraints imposed by its default decision.

\subsection{Recursive formulation}

We consider a Markov equilibrium, in which all policies depend on the payoff-relevant states $(b, a, s)$ where $s \equiv\{y, \omega\}$. Let $d$ denote the current-period default decision. We assume that $d$ is equal to 1 if the government defaulted in the current period and is equal to 0 if it did not. Let $V$ denote the government's value function at the beginning of a period, that is, before the default decision is made. Let $V_{0}$ denote the value function of a sovereign not in default. Let $V_{1}$ denote the value function of a sovereign in default. For any bond price function $q$, the function $V$ satisfies the following functional equation:

$$
V(b, a, s)=\max _{d \in\{0,1\}}\left\{d V_{1}(a, s)+(1-d) V_{0}(b, a, s)\right\},
$$

where

$$
V_{0}(b, a, s)=\max _{b^{\prime}, a^{\prime}, c}\left\{u(c)+\beta \mathbb{E}_{s^{\prime} \mid s} V\left(b^{\prime}, a^{\prime}, s^{\prime}\right)\right\},
$$

subject to

$$
c+g+\kappa[1+\phi(y-\bar{y})] b+a^{\prime} q_{a}=y+q\left(b^{\prime}, a^{\prime}, s\right)\left(b^{\prime}-(1-\delta) b\right)+a
$$

where $\kappa[1+\phi(y-\bar{y})]$ is the contingent coupon obligation and $g$ represents a time-invariant level of government spending (capturing the role of budget rigidities). The value of default is:

$$
V_{1}(a, s)=\max _{a^{\prime}}\left\{u\left(y+a-g-a^{\prime} q_{a}\right)-\psi_{d}(y)+\beta \mathbb{E}_{s^{\prime} \mid s} V\left(0, a^{\prime}, s^{\prime}\right)\right\} .
$$

A Markov perfect equilibrium is then defined as follows.

Definition 1 (Markov perfect equilibrium). A Markov perfect equilibrium is defined by value functions $\left\{V(b, a, s), V_{0}(b, a, s), V_{1}(a, s)\right\}$, associated policy functions $\{\hat{d}(b, a, s), \hat{a}(b, a, s), \hat{b}(b, a, s)\}$, and a bond price schedule $q\left(b^{\prime}, a^{\prime}, s\right)$ such that

1. given the bond price schedule, policy functions solve problems (B.10) - (6), 
2. the bond price schedule satisfies the bond pricing equation

$$
q\left(b^{\prime}, a^{\prime}, s\right)=\mathbb{E}_{s^{\prime} \mid s}\left\{m\left(s^{\prime}, s\right)\left[1-\hat{d}\left(b^{\prime}, a^{\prime}, s^{\prime}\right)\right]\left[\kappa\left(1+\phi\left(y^{\prime}-\bar{y}\right)\right)+(1-\delta) q\left(b^{\prime \prime}, a^{\prime \prime}, s^{\prime}\right)\right]\right\},
$$

where

$$
b^{\prime \prime}=\hat{b}\left(b^{\prime}, a^{\prime}, s^{\prime}\right) \text { and } a^{\prime \prime}=\hat{a}\left(b^{\prime}, a^{\prime}, s^{\prime}\right) .
$$

\subsection{Numerical solution and calibration}

We refer to the model with non-state contingent coupons (i.e. with $\phi=0$ ) as the benchmark model and calibrate it following Bianchi et al. (2018).

Numerical Solution. As in Hatchondo et al. (2010), we solve for the equilibrium by computing the limit of the finite-horizon version of our economy. The recursive government problem is solved using value function iteration. For each state, we solve the optimal portfolio allocation by searching over a grid of debt and reserve levels and then using the best portfolio on that grid as an initial guess in a nonlinear optimization routine. The value functions $V_{0}$ and $V_{1}$ and the

function that indicates the equilibrium bond price $q(\hat{b}(\cdot), \hat{a}(\cdot), s)$ are approximated using linear interpolation over $y$ and cubic spline interpolation over debt and reserves positions.

Calibration. Since our benchmark model (imposing $\phi=0$ ) is identical to the model in Bianchi et al. (2018) we use their same calibration strategy. A period in the model refers to a year. We split the parameters of the model into two groups. The first group of parameters (those in the top part of Table 1) take values that can be set either directly from the data or using typical values from the literature. The second group of parameter values (those in the bottom part of Table 1) are set by simultaneously matching key moments from the data.

We assume the following functional form for the utility cost of default,

$$
\psi_{d}(y)=\psi_{0}+\psi_{1} \log (y)
$$

As in Chatterjee and Eyigungor (2012), having two parameters in the cost of default gives us enough flexibility to match the spread dynamics observed in the data.

The parameter values that govern the tradable endowment process are chosen to mimic the 
Table 1: Parameter values for the benchmark model.

\begin{tabular}{llc}
\hline \hline Parameter & Description & Value \\
\hline$r$ & Risk-free rate & 0.04 \\
$\beta$ & Domestic discount factor & 0.92 \\
$\pi_{L H}$ & Prob. of transitioning to high risk premium & 0.15 \\
$\pi_{H L}$ & Prob. of transitioning to low risk premium & 0.8 \\
$\sigma_{\varepsilon}$ & Std. dev. of innovation to log $(y)$ & 0.034 \\
$\rho$ & Autocorrelation of log $(y)$ & 0.66 \\
$\mu_{y}$ & Mean of log $(y)$ & $-\frac{1}{2} \sigma_{\varepsilon}^{2}$ \\
$g$ & Government consumption & 0.12 \\
$\delta$ & Coupon decaying rate & 0.2845 \\
$\kappa$ & Avg. coupon size & $(r+\delta) e^{-r}$ \\
& Parameters set by simulation & \\
\hline & & \\
$\gamma$ & Coefficient of relative risk aversion & 3.3 \\
$\psi_{0}$ & Default cost parameter & 2.45 \\
$\psi_{1}$ & Default cost parameter & 19 \\
$\omega_{H}$ & Pricing kernel parameter & 23 \\
\hline \hline
\end{tabular}

behavior of logged and linearly detrended GDP for Mexico. This yields $\sigma_{\varepsilon}=0.034$ and $\rho=0.66{ }^{14}$ We set $\mu_{y}=-\frac{1}{2} \sigma_{\varepsilon}^{2}$ so that mean income is normalized to one (i.e. $\bar{y}=1$ ).

The values of the risk-free interest rate and the domestic discount factor are set to $r=0.04$ and $\beta=0.92$, which are standard in quantitative sovereign default studies. The level of government spending is set to $12 \%$ of GDP (as found in Mexican data).

We set $\delta=0.2845$. With this value and the targeted level of sovereign spread, sovereign debt in the simulations has an average duration of three years, which is roughly the average duration of public debt in Mexico. ${ }^{15}$ The parameter governing the average size of the bond coupon payments is normalized to $\kappa=(r+\delta) e^{-r}$, which ensures that a default-free bond (with the same coupon structure of our sovereign bonds) trades at a price of $e^{-r}$.

Bianchi et al. (2018) use the average EMBI+ spread to parameterize the shock process to lenders' risk aversion. They assume that a period with high lenders' risk aversion is one in which the global EMBI+ without countries in default is one standard deviation above the median over the sample period. With this procedure, they obtain three episodes of a high risk premium every 20 years with an average duration equal to 1.25 years for each episode, which implies $\pi_{L H}=0.15$ and $\pi_{H L}=0.8$. On average, the global EMBI+ was 2 percentage points higher in those episodes

\footnotetext{
${ }^{14}$ Mexico is a common reference for studies on emerging economies because its business cycle displays the same properties that are observed in other emerging economies (Aguiar and Gopinath, 2007, Neumeyer and Perri, 2005, and Uribe and Yue, 2006).

${ }^{15}$ We use the Macaulay definition of duration that, with the coupon structure in this paper, is given by $D=\left(1+i_{b}\right) /\left(\delta+i_{b}\right)$, where $i_{b}$ denotes the constant per-period yield delivered by the bond.
} 
than in normal periods.

Targeted moments. The calibration strategy described so far leaves four parameters to assign values to: the default cost parameters $\left(\psi_{0}\right.$ and $\left.\psi_{1}\right)$, the risk premium parameter $\left(\omega_{H}\right)$, and the risk aversion parameter $(\gamma)$. Bianchi et al. (2018) target four moments: (i) a mean debt-to-GDP ratio of $43.5 \%$, (ii) a mean sovereign spread of $2.4 \%$, (iii) an increase of 200 basis points in the spread during high-risk premium periods, and (iv) a volatility of consumption relative to output equal to 1.

\subsection{Quantitative results}

Business cycle statistics. The first two columns of Table 2 show that the simulations of the benchmark model match well the targeted moments. The model also does a good job in mimicking other non-targeted moments. In particular, the model is able to capture the countercyclicality of sovereign spreads and the procyclicality of consumption. As mentioned by Bianchi et al. (2018), this calibration strategy produces a mean reserves-to-GDP ratio that is roughly $70 \%$ of the one in the data (6\% vs. $8.5 \%$ ).

Table 2: Key statistics - model and data.

\begin{tabular}{lccc}
\hline \hline & Data & \multicolumn{2}{c}{ Model } \\
& & $\begin{array}{c}\text { Benchmark } \\
(\phi=0)\end{array}$ & $\begin{array}{c}\text { Indexed debt } \\
(\phi=1)\end{array}$ \\
\hline Targeted & & & \\
Mean debt $(b / y)$ & 43.5 & 43.3 & 54.2 \\
Mean $r_{s}$ (in \%) & 2.4 & 2.4 & 2.6 \\
$\Delta r_{s}$ w/ risk-prem. shock & 2.0 & 2.2 & 2.8 \\
$\sigma(c) / \sigma(y)$ & 1.0 & 1.0 & 0.9 \\
\hline Non-Targeted & & & \\
$\sigma\left(r_{s}\right)$ (in $\left.\%\right)$ & 0.9 & 2.0 & 2.5 \\
$\rho\left(r_{s}, y\right)$ & -0.5 & -0.7 & -0.8 \\
$\rho(c, y)$ & 0.8 & 0.9 & 0.9 \\
Mean Reserves $(a / y)$ & 8.5 & 6.0 & 11.9 \\
\hline \hline
\end{tabular}

Note: Moments in the model are computed for the average of pre-default simulation samples. We simulate the model for 1,000 samples of 300 periods each. We then take the last 35 observations of each sample in which the last default was observed at least 25 periods before the beginning of the sample. The 'Data' column is the one reported in Bianchi et al. (2018) and corresponds to Mexico. 
Indexed debt. The last column of Table 2 has the simulated moments for the case in which the government uses indexed debt (with $\phi=1$, as in Roch and Roldan, 2021). ${ }^{16}$ There are some notable differences. First, the government optimally chooses to hold a much higher debt ratio ( $55 \%$ vs. $43.5 \%$ ). Second, this higher debt ratio is mostly used to finance the hoarding of international reserves: the indexed debt version features a ratio of reserves-to-income that is roughly double of the one seen in the benchmark model. ${ }^{17}$ Third, this different portfolio has a non-trivial impact on the equilibrium spreads: using indexed debt, this substantially higher indebtedness level implies only a slightly higher average spread - this is the joint effect of having more reserves and using state contingent debt (which lowers coupon payments in times of distress). Fourth, as expected, using state contingent debt delivers a smoother path for consumption.

The state contingency afforded by the indexed debt implies that, on the margin, higher debt has a smaller effect on spreads resulting in a flatter spread-debt menu. For low debt levels, where one-period ahead default probability is low, lenders penalize the use of indexed debt and demand slightly higher spreads. For high debt levels, where the default probability is substantial, the use of indexed debt helps avoid defaults and therefore comes at cheaper rates. Figure 2 shows this.

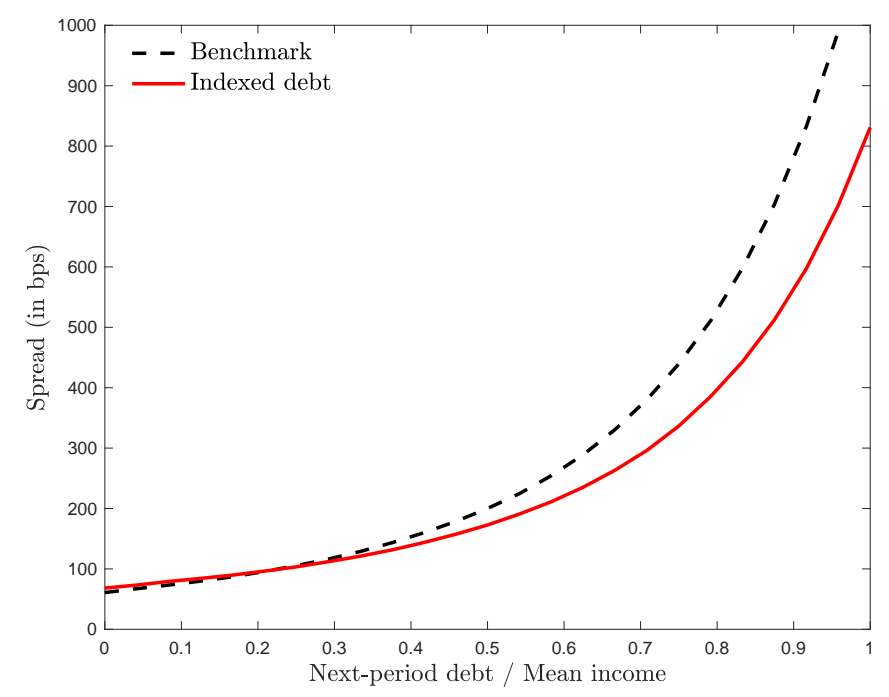

Figure 2: Spread-debt menus and debt indexation

Note: The figure is computed for the mean income and reserve levels in the simulations of each model, and assuming no risk-premium shock in the current period $\left(\omega_{t}=0\right)$.

\footnotetext{
${ }^{16}$ Note that in this version we do not recalibrate the model, but just modify the value of $\phi$ from zero to one. Both Durdu (2009) and Roch and Roldan (2021) compute ex-ante optimal configurations for the debt indexation in models (related to but) different from ours.

${ }^{17}$ Comparing with other models using state contingent sovereign debt (e.g., Alfaro and Kanczuk, 2019), our model delivers an equilibrium portfolio that is closer to the data: a reserves-to-debt ratio that is roughly $20 \%$. As a reference point, Alfaro and Kanczuk (2019) find this ratio to be above $80 \%$.
} 
Therefore, as shown in Figure 2, a testable implication of our theory is that, for a given level of debt, financing reserve accumulation with contingent debt (in particular, using an instrument indexed to the performance of domestic income) allows the country to pay lower spreads than it would otherwise (i.e., had it used non-state contingent debt instead).

\section{Taking the model to the data}

\subsection{Data description}

We now take the model to the data by estimating the effect of how reserves are accumulated on government bond spreads. While the relationship between spreads and reserves has been established (see for example, Levy-Yeyati and Gómez, 2020), in this paper we will focus on the whether the effects differ depending on how reserves are financed.

In order to estimate the effect of different forms of reserve accumulation we are aided by the fact that the IMF has worked to produce standardized data for central bank (Cartas and Harutyunyan (2017)). The IMF data starts from a common balance sheet for the central bank, and has managed to fit into this format data from around 145 countries with temporal coverage, at the time of writing, running up to 2018. Appendix A lists the countries included in this sample. This homogeneous structure includes the following items,

\section{Balance Sheet}

Claims on non-residents (1)

Claims on others depository corporations (2)

Net Claims on Central Government (3)
Liabilities to non-residents (a)

Monetary base (b)

Other Liabilities To Other Depository Corporations (c)

Deposits and Securities other than Shares Excluded from Monetary Base (d)

Loans (e)

Financial Derivatives (f)

Shares and equity $(\mathrm{g})$

Other items. (h)

To estimate the separate effects of accumulating reserves from its three financing sources: 
foreign liabilities, unsterilized purchases, and domestic currency liabilities, we construct the following variables:

Reserve Ratio $=(1) / G D P$,

Remunerated Domestic Liabilities $=[(c)+(d)+(e)+(f)] / G D P$,

Unsterilized Purchases $=(b) / G D P$,

External Liabilities $=(a) / G D P$.

Other Balance Sheet $=[(g)+(h)-(2)-(3)] / G D P$

The first variable, Reserve Ratio, is just the total claims on non-residents (largely made up of gross reserves), which is the number typically used in the literature. Remunerated Domestic Liabilities is the amount of liabilities issued by the central bank in domestic currency. Unsterilized Purchases is defined as the Monetary Base and will capture the amount of reserves that has been financed by unsterilized purchases. External Liabilities represents liabilities incurred with nonresidents. Other Balance Sheet groups the remaining terms of the balance sheet.

Of course these variables can also move without affecting reserves. For example, the central bank can issue domestic liabilities, or even foreign liabilities, to sterilize money demand, or money can be issued to finance the treasury and thus credited in the domestic credit account on the asset side. So, our identification strategy will be to assess the impact of reserves on spreads by holding constant all but one of the items in the balance sheet. In this way we can isolate the impact of a change in reserves arising from these three sources: external liabilities, domestic liabilities and unsterilized interventions.

In our empirical specification below the accumulation of reserves with domestic currency liabilities will be our proxy for what we called in the model "state contingent" debt. This analogy was illustrated by the historical example in section 1.1, where we showed how domestic currency debt falls in value during crisis events. Alfaro and Kanczuk (2019) also model the hedging alternative to accumulate reserves as issuing debt denominated in domestic non-tradable units.

To empirically assess the validity of the model we follow two approaches. First, we construct a panel of spreads for the countries included in the IMF's central bank balance sheet database and estimate the effect of the different ways of accumulating reserves on sovereign spreads. Second, we look at exogenous shocks to spreads, identified by large swings in the VIX index, and assess whether the way reserves were accumulated mattered for the change in sovereign spreads during those events. We find that both approaches deliver results consistent with the model, validating the hypothesis that the way reserves are accumulated does matter: financing reserves 
with domestic currency denominated debt (again, our proxy for 'state contingent' debt in the model), by providing better hedging during negative events, lowers spreads in a way that reserves buildup with foreign liabilities does not.

\subsection{Cross country evidence}

Table 3 shows the main results of the paper for the log-spread. As control variables, in order to limit our degrees of freedom when choosing the specification, we decided to restrict ourselves to those used in independent work. In particular, we follow Levy-Yeyati and Gómez (2020), who have a direct test of the effect of reserves on spreads. In this way, we only modify the reserve variable, splitting the effect for the different mechanisms for financing reserves. The specification we build upon includes a measure for the degree of risk aversion in the market, defined as the spreads between an Option-Adjusted Spreads (OAS) index of all bonds in a given rating category and the Treasury curve (ICE BofAML Option-Adjusted Spreads constructed by Merrill Lynch); it also includes the rating of the country's debt constructed by S\&P for long-term debt denominated in foreign currency of each country; the world interest rate, defined as the US Treasury 10 year constant maturity yield; and a measure of the stock of private and public debt (taken from World Bank). ${ }^{18}$ Our data is at a monthly frequency. GDP data is smoothed to monthly frequency using splines. In some specifications we use year and country fixed effects. Appendix A lists the variables and sources.

Columns (1) and (2) in Table 3 extend the results in Levy-Yeyati and Gómez (2020), with and without country fixed effects, to a larger number of countries. All the coefficients have the expected signs and are strongly statistically significant (the sole exception being the world interest rate in the specification with country fixed effects). Most relevant to the discussion here is the negative coefficient of reserves on spreads. An increase of $1 \%$ in the reserve to GDP ratio appears to be associated with a reduction in spreads by between 2.6 and $2.8 \%$.

Columns (3) to (5) in Table 3 split the effect of reserves on spreads depending on how the reserves are accumulated. Column (3), for example, adds as controls the amount of domestic liabilities and the unsterilized purchases terms, thus controlling for these two variables. We can then reinterpret the reserve coefficient in column (3) as that obtained from changing reserves by accumulating foreign liabilities. The fact that the coefficient is not significant indicates that

\footnotetext{
${ }^{18}$ As a robustness check we added the fiscal deficit and current account imbalances but they both do not appear statistically significant given the other control variables. In turn, the coefficients of the other controls do not change. See Table C.1 in Appendix C.
} 
Table 3: Regression results. Full Sample

\begin{tabular}{|c|c|c|c|c|c|c|c|c|}
\hline & \multicolumn{8}{|c|}{ Dependent variable: log(spread) } \\
\hline & (1) & $(2)$ & (3) & (4) & (5) & (6) & (7) & (8) \\
\hline Risk Aversion & $\begin{array}{c}0.76^{* * *} \\
(0.02)\end{array}$ & $\begin{array}{c}0.78^{* * *} \\
(0.06)\end{array}$ & $\begin{array}{c}0.77^{* * *} \\
(0.06)\end{array}$ & $\begin{array}{c}0.78^{* * *} \\
(0.06)\end{array}$ & $\begin{array}{c}0.77^{* * *} \\
(0.06)\end{array}$ & $\begin{array}{c}0.95^{* * *} \\
(0.04)\end{array}$ & $\begin{array}{c}0.96^{* * *} \\
(0.04)\end{array}$ & $\begin{array}{c}0.96^{* * *} \\
(0.04)\end{array}$ \\
\hline Rating & $\begin{array}{c}-0.36^{* * *} \\
(0.03)\end{array}$ & $\begin{array}{c}-0.35^{* * *} \\
(0.11)\end{array}$ & $\begin{array}{c}-0.33^{* * *} \\
(0.11)\end{array}$ & $\begin{array}{c}-0.33^{* * *} \\
(0.10)\end{array}$ & $\begin{array}{c}-0.33^{* * *} \\
(0.10)\end{array}$ & $\begin{array}{c}-0.33^{* * *} \\
(0.10)\end{array}$ & $\begin{array}{c}-0.32^{* * *} \\
(0.10)\end{array}$ & $\begin{array}{c}-0.32^{* * *} \\
(0.10)\end{array}$ \\
\hline World Rate & $\begin{array}{c}-0.29^{* * *} \\
(0.02)\end{array}$ & $\begin{array}{l}-0.17 \\
(0.11)\end{array}$ & $\begin{array}{l}-0.19^{*} \\
(0.11)\end{array}$ & $\begin{array}{l}-0.17 \\
(0.11)\end{array}$ & $\begin{array}{l}-0.18^{*} \\
(0.11)\end{array}$ & $\begin{array}{c}0.20^{* * *} \\
(0.04)\end{array}$ & $\begin{array}{c}0.20^{* * *} \\
(0.04)\end{array}$ & $\begin{array}{c}0.20^{* * *} \\
(0.04)\end{array}$ \\
\hline Reserve Ratio & $\begin{array}{c}-2.58^{* * *} \\
(0.11)\end{array}$ & $\begin{array}{c}-2.76^{* * *} \\
(0.55)\end{array}$ & $\begin{array}{l}-0.68 \\
(0.97)\end{array}$ & $\begin{array}{c}-3.56^{* * *} \\
(0.33)\end{array}$ & $\begin{array}{c}-3.17^{* * *} \\
(0.94)\end{array}$ & $\begin{array}{l}-0.25 \\
(1.04)\end{array}$ & $\begin{array}{c}-3.24^{* * *} \\
(0.43)\end{array}$ & $\begin{array}{c}-2.85^{* * *} \\
(1.08)\end{array}$ \\
\hline Sovereign Debt & $\begin{array}{c}1.53^{* * *} \\
(0.05)\end{array}$ & $\begin{array}{c}1.56^{* * *} \\
(0.53)\end{array}$ & $\begin{array}{l}1.31^{* *} \\
(0.54)\end{array}$ & $\begin{array}{l}1.14^{* *} \\
(0.50)\end{array}$ & $\begin{array}{l}1.14^{* *} \\
(0.50)\end{array}$ & $\begin{array}{c}1.02 \\
(0.66)\end{array}$ & $\begin{array}{c}0.86 \\
(0.63)\end{array}$ & $\begin{array}{c}0.86 \\
(0.63)\end{array}$ \\
\hline Private Debt & $\begin{array}{c}0.74^{* * *} \\
(0.05)\end{array}$ & $\begin{array}{c}1.01^{* * *} \\
(0.31)\end{array}$ & $\begin{array}{c}1.11^{* * *} \\
(0.42)\end{array}$ & $\begin{array}{l}1.05^{* *} \\
(0.44)\end{array}$ & $\begin{array}{c}1.08^{* * *} \\
(0.38)\end{array}$ & $\begin{array}{l}1.00^{* *} \\
(0.43)\end{array}$ & $\begin{array}{l}0.94^{* *} \\
(0.44)\end{array}$ & $\begin{array}{l}0.96^{* *} \\
(0.41)\end{array}$ \\
\hline $\begin{array}{l}\text { Remunerated } \\
\text { Domestic Liabilites }\end{array}$ & & & $\begin{array}{c}-3.10^{* *} \\
(1.30)\end{array}$ & & $\begin{array}{l}-0.31 \\
(1.16)\end{array}$ & $\begin{array}{c}-3.27^{* *} \\
(1.46)\end{array}$ & & $\begin{array}{l}-0.43 \\
(1.18)\end{array}$ \\
\hline $\begin{array}{l}\text { Unsterilized } \\
\text { Purchases }\end{array}$ & & & $\begin{array}{l}-2.44^{*} \\
(1.47)\end{array}$ & $\begin{array}{c}0.50 \\
(1.35)\end{array}$ & & $\begin{array}{l}-2.54 \\
(1.56)\end{array}$ & $\begin{array}{c}0.43 \\
(1.29)\end{array}$ & \\
\hline $\begin{array}{l}\text { Others } \\
\text { Balance Sheet }\end{array}$ & & & $\begin{array}{c}-1.77^{*} \\
(1.01)\end{array}$ & $\begin{array}{l}1.55^{* *} \\
(0.61)\end{array}$ & $\begin{array}{c}1.14 \\
(0.96)\end{array}$ & $\begin{array}{c}-1.89^{*} \\
(1.05)\end{array}$ & $\begin{array}{l}1.51^{* *} \\
(0.60)\end{array}$ & $\begin{array}{l}1.10 \\
(1.04)\end{array}$ \\
\hline External Liabilities & & & & $\begin{array}{c}4.71^{* * *} \\
(1.14)\end{array}$ & $\begin{array}{c}4.29^{* * *} \\
(0.89)\end{array}$ & & $\begin{array}{c}4.74^{* * *} \\
(1.16)\end{array}$ & $\begin{array}{c}4.32^{* * *} \\
(0.97)\end{array}$ \\
\hline Constant & $\begin{array}{c}2.29^{* * *} \\
(0.15)\end{array}$ & & & & & & & \\
\hline $\begin{array}{l}\text { Fixed effects? } \\
\text { Year dummies? } \\
\text { Observations } \\
\text { Adjusted } \mathrm{R}^{2}\end{array}$ & $\begin{array}{l}\text { No } \\
\text { No } \\
4,497 \\
0.52\end{array}$ & $\begin{array}{c}\text { Yes } \\
\text { No } \\
4,497 \\
0.57\end{array}$ & $\begin{array}{c}\text { Yes } \\
\text { No } \\
4,497 \\
0.58\end{array}$ & $\begin{array}{c}\text { Yes } \\
\text { No } \\
4,497 \\
0.59\end{array}$ & $\begin{array}{c}\text { Yes } \\
\text { No } \\
4,497 \\
0.59\end{array}$ & $\begin{array}{c}\text { Yes } \\
\text { Yes } \\
4,497 \\
0.62\end{array}$ & $\begin{array}{c}\text { Yes } \\
\text { Yes } \\
4,497 \\
0.63\end{array}$ & $\begin{array}{c}\text { Yes } \\
\text { Yes } \\
4,497 \\
0.63\end{array}$ \\
\hline
\end{tabular}

Note: Robust standard errors in parentheses. Risk Aversion, Rating and World rate are expressed in logs, the remaining variables are ratios of GDP. ${ }^{*} \mathrm{p}<0.1 ;{ }^{* *} \mathrm{p}<0.05 ;{ }^{* * *} \mathrm{p}<0.01$

there is no impact on spreads from accumulating reserves through this channel. Column (4) fixes unsterilized purchases and foreign liabilities, so the reserve coefficient in this column identifies the effects of reserve purchases using domestic debt. The coefficient here not only becomes significant but also larger than in the original specification, now a 1\% increase in the reserves to GDP ratio 
accumulated through this channel is associated to a reduction in spreads of $3.6 \%$. Column (5) shows the effect of accumulating reserves through unsterilized purchases, the effect is again significant but with a point estimate that is lower than that corresponding to the accumulation of reserves through issuing domestic currency debt. In this case a $1 \%$ increase in reserves reduces spreads by $3.2 \%$. These results remain basically unchanged when introducing year fixed effects in columns (6) to (8).

The purpose of this paper is to show that the way reserves are financed matters. To make this point more clearly, in Table 4 we show the p-values of the test of differences between the coefficients of reserves across different specifications. ${ }^{19}$ The table shows that the effect on spreads of accumulating reserves with external liabilities is statistically different from that resulting from accumulating reserves with domestic denominated liabilities. In turn, the null hypothesis that the coefficients of accumulating with domestic liabilities and through unsterilized purchases are the same cannot be rejected at standard values.

Table 4: Difference Test Between Coefficients

\begin{tabular}{|c|c|c|c|c|}
\hline & Reserve Ratio & $\mathrm{p}$-value & Reserve Ratio & p-value \\
\hline & EL - DL & $0.00^{* * *}$ & EL - DL & $0.01^{* * *}$ \\
\hline & $\mathrm{DL}-\mathrm{U}$ & 0.70 & $\mathrm{DL}-\mathrm{U}$ & 0.74 \\
\hline Year FE & No & & Yes & \\
\hline
\end{tabular}

Note: 'EL', 'DL', and 'U' stand for 'External liabilities', 'Domestic liabilities' and 'Unsterilized purchases', respectively. For example, 'EL-DL' in the upperleft corner refers to the difference in the coefficient for Reserve Ratio across specifications (3) and (4) in Table $3 .{ }^{*} \mathrm{p}<0.1 ;{ }^{* *} \mathrm{p}<0.05 ;{ }^{* * *} \mathrm{p}<0.01$.

Robustness. In Table 5 we test a number of hypotheses to provide robustness to our assertion that the way reserves are accumulated matters. For brevity, Table 5 only shows the coefficient of the reserves variable, as the coefficients of the other variables are relatively stable, and similar to those shown in Table $3 .^{20}$

Our first robustness check feeds directly from the model of section 2 which shows that accumulating reserves with state contingent debt (in our empirical exercise we proxy by domestic currency denominated debt), has a stronger negative effect on spreads at larger levels of debt than at lower levels of debt. The first row of Table 5 splits the observations by level of debt.

\footnotetext{
${ }^{19}$ Where the formula for the z-test is given by $Z=\frac{\beta_{1}-\beta_{2}}{\sqrt{S E\left(\beta_{1}\right)^{2}+S E\left(\beta_{2}\right)^{2}}}$.

${ }^{20}$ The full regressions are included in Tables C.2, C.3, C.4, C.5, and C.6 in Appendix C.
} 
In order to have a reasonable separation, we use the lowest and highest terciles of the debt to GDP ratio to split observations into 'Low Debt' and 'High Debt', respectively. Consistent with the model, the results indicate that for low levels of debt, the effect of reserves is insignificant (regardless of the way they are accumulated), whereas it is significant and negative for higher levels of debt and when reserves are accumulated through contingent debt. ${ }^{21}$ These results carry, in the second row, to the case when we split the countries between 'Low Spread' and 'High Spread' observations according to their median spreads.

The model suggests that credit constrained or more vulnerable countries (with higher spreads) will benefit more from accumulating reserves through instruments that provide a better hedge in times of need. Thus, an alternative way to assess the predictions of the model is to look for variables that signal macroeconomic instability. The third row in Table 5 provides one such alternative, by splitting the sample into 'High' and 'Low' devaluation rate countries. We define countries with high devaluation rates as those that depreciated their currencies by more than $5 \%$ per year on average. This group comprises $60 \%$ of the sample. This exercise shows that our main empirical results arise basically from the 'High Devaluation Rate' countries: as suggested by the model the value of reserve accumulation is not as relevant in economies with stable macroeconomic frameworks. Similar results are obtained when splitting the sample between high interest rates and high inflation rates, but we do not show these results here for brevity of exposition. $^{22}$

The final two rows of Table 5 dwell a bit further into this hypothesis, by looking at countries that have large fiscal deficits compared to those that have low deficits, and by looking at countries that have higher degrees of dollarization. The results are similar with some caveats. When considering the group of countries that exhibit on average large primary deficits (in the forth row of Table 5), ${ }^{23}$ all forms of accumulating reserves reduce country spreads. Thus, for these countries the value of reserves seems to be paramount. Again, accumulating reserves through the issue of domestic currency denominated liabilities seems the most effective mechanism. In fact, for these countries the coefficient indicates a $7.4 \%$ reduction in spreads for each additional point in the reserves to GDP ratio accumulated in this way. For countries with solid fiscal accounts,

\footnotetext{
${ }^{21}$ An alternative approach splits the countries into 'High Debt' countries and 'Low Debt' countries. To do so we look at the country specific average debt levels throughout the sample and then use the lowest and highest terciles of the average debt levels to split the countries into the two groups. The results also indicate that the coefficient of state contingent debt is larger in absolute value when debt is high. See Table C.7 in Appendix C.

${ }^{22}$ These results are presented in Table C.8 in Appendix C.

${ }^{23} \mathrm{We}$ use "Primary net lending/borrowing (also referred as primary balance) (\% of GDP) (GGXONLB_G01_GDP_PT)" from IMF. Annual primary deficits are calculated to maximize sample size.
} 
Table 5: Regression results. Robustness

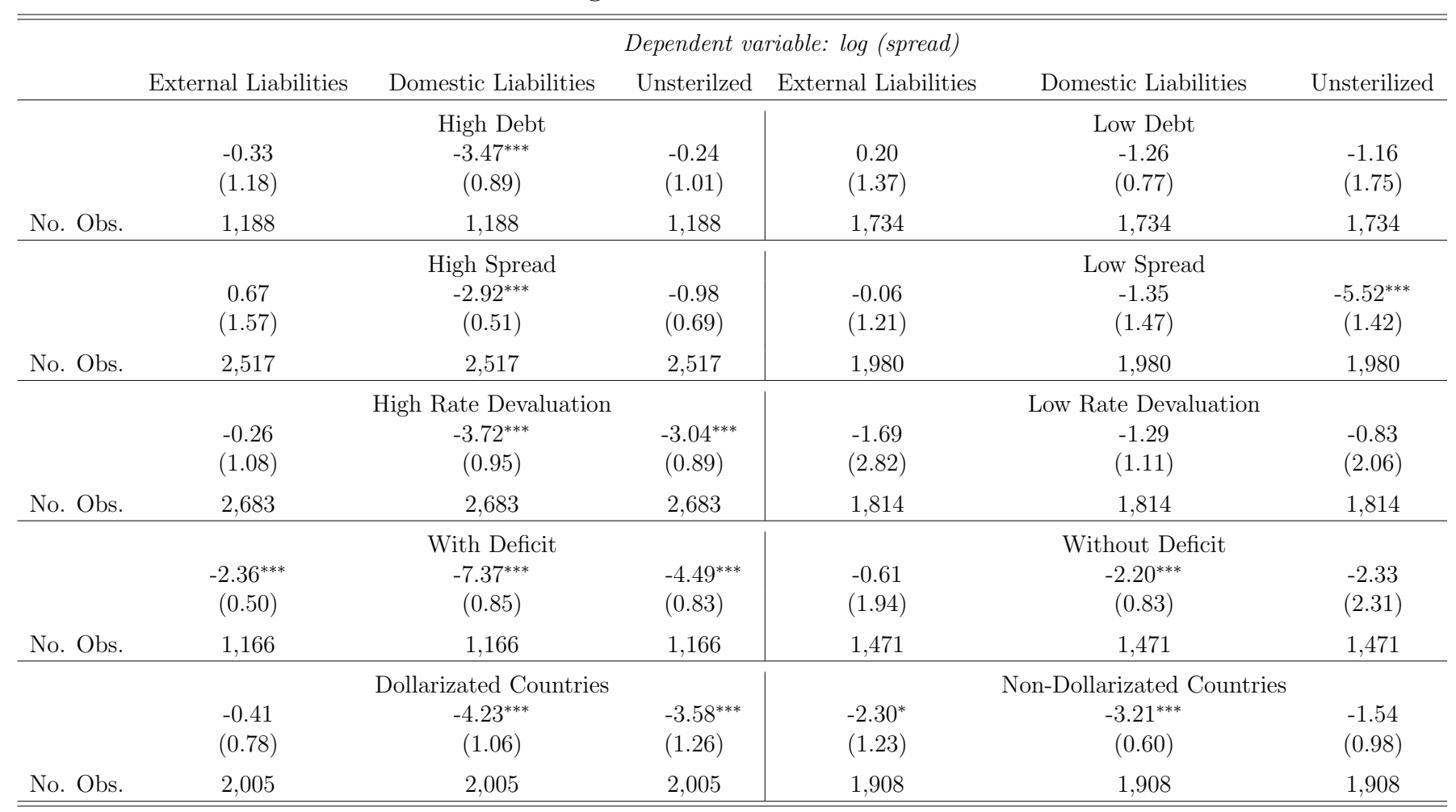

Note: Robust standard errors in parentheses. All specifications include country and year fixed effects. ${ }^{*} \mathrm{p}<0.1 ;{ }^{* *} \mathrm{p}<0.05 ;{ }^{* * *} \mathrm{p}<0.01$

only the coefficient on the domestic liabilities financing coefficient remains significant. ${ }^{24}$

Another way of capturing macroeconomic weakness is using a dollarization variable. We split the sample between countries with average deposits in dollars amounting to $20 \%$ or more of total deposits ("dollarized countries") and the rest. Data is taken from (Levy-Yeyati, 2006). Again, as shown in the last row of Table 5, countries with substantial dollarization do not benefit from accumulating reserves with foreign liabilities, whereas countries with low levels of dollarization show a mild improvement, hinting that the weaker effect of accumulating reserves with foreign liabilities may come from dollarized economies.

Table 6 shows that the effect on spreads of accumulating reserves with external liabilities is statistically different from that resulting from accumulating reserves with domestic currency denominated liabilities, and that this is true for all the robustness checks presented in Table 5 in high macroeconomic vulnerable environments (the first two columns of Table 6). Moreover, in three out of five cases, the coefficients of accumulating with domestic currency denominated liabilities and unsterilized purchases are also statistically different from each other, at standard

\footnotetext{
${ }^{24}$ For the robustness exercises in the last two rows of Table 5, we verified that the coefficients using these subsamples are similar to those of the original sample. The full regressions are in Table C.9 in Appendix C.
} 
Table 6: Difference Test Between Coefficients. Split Sample

\begin{tabular}{|c|c|c|c|}
\hline Reserve Ratio & p-value & Reserve Ratio & p-value \\
\hline \multicolumn{2}{|c|}{ High Debt } & \multicolumn{2}{|c|}{ Low Debt } \\
\hline EL - DL & $0.03^{* *}$ & EL-DL & 0.35 \\
\hline $\mathrm{DL}-\mathrm{U}$ & $0.02^{* *}$ & $\mathrm{DL}-\mathrm{U}$ & 0.96 \\
\hline \multicolumn{2}{|c|}{ High Spread } & \multicolumn{2}{|c|}{ Low Spread } \\
\hline EL - DL & $0.03^{* *}$ & EL-DL & 0.50 \\
\hline $\mathrm{DL}-\mathrm{U}$ & $0.02^{* *}$ & DL - U & $0.04^{* *}$ \\
\hline \multicolumn{2}{|c|}{ High Rate Devaluation } & \multicolumn{2}{|c|}{ Low Rate Devaluation } \\
\hline EL - DL & $0.02^{* *}$ & EL-DL & 0.89 \\
\hline $\mathrm{DL}-\mathrm{U}$ & 0.60 & $\mathrm{DL}-\mathrm{U}$ & 0.84 \\
\hline \multicolumn{2}{|c|}{ With Deficit } & \multicolumn{2}{|c|}{ Without Deficit } \\
\hline EL - DL & $0.00^{* * *}$ & EL-DL & 0.45 \\
\hline DL - U & $0.01^{* * *}$ & DL - U & 0.96 \\
\hline \multicolumn{2}{|c|}{ Dollarizated Countries } & \multicolumn{2}{|c|}{ Non-Dollarizated Countries } \\
\hline EL - DL & $0.00^{* * *}$ & EL-DL & 0.51 \\
\hline DL - U & 0.69 & DL - U & 0.15 \\
\hline
\end{tabular}

Note: 'EL', 'DL', and 'U' stand for 'External liabilities', 'Domestic liabilities' and 'Unsterilized purchases', respectively. ${ }^{*} \mathrm{p}<0.1$; ${ }^{* *} \mathrm{p}<0.05 ;{ }^{* * *} \mathrm{p}<0.01$.

values. Notably, these statistical differences disappear (almost entirely) when focusing on less macro-vulnerable environments (last two columns in Table 6).

\subsection{Exogenous shocks}

The use of cross country regressions, even when controlling for country and year effects, is subject to endogeneity concerns. In this section we therefore attempt to test the hypothesis in a context where the exogeneity of the shocks is established on firmer ground. To do so, we follow Rey (2013) and Acharya and Krishnamurthy (2019) in using the VIX index as a way of identifying large exogenous shocks, as they are associated to global shocks independent of each particular country.

We identify as large shocks to the VIX all the dates in which the following two conditions are met: (i) first, the difference in value of the VIX index relative to its average during the interval comprising 5 and 10 days before each date is larger than 20, and (ii) additionally, we require that 
the cross country average increase in sovereign spreads is at least 10 basis points. ${ }^{25}$ This last restriction insures that the shocks that we discuss have at least a minimal relevance for sovereign spreads. This simple rule identifies, in the 2009-2019 time period considered, three episodes of sharp increases in the index shown in Figure 3.

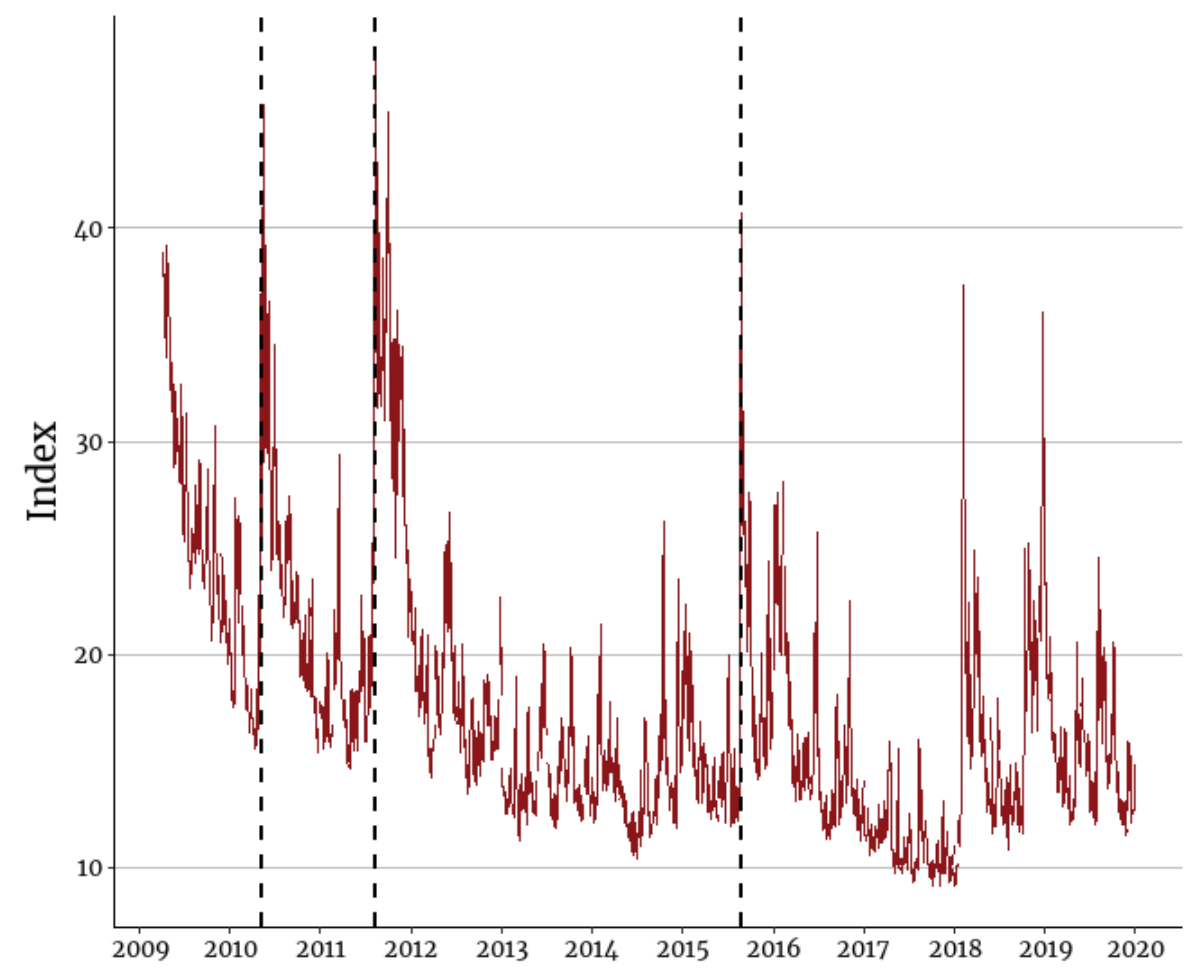

Figure 3: VIX Index

These three large episodes ${ }^{26}$ include the 7 th of May 2010, following the flash crash in the US stock market the previous day, the 8th of August of 2011 known as the "Black Monday" of 2011 as a result of S\&P's downgrade of US debt, and the 24th August of 2015, a second flash crash of the US stock market. All of these events are clearly exogenous to the emerging economies we consider.

For each of these episodes we compute the change in the CDS spreads for the day of the event and then check if the way reserves have been accumulated matters for this jump in spreads.

Figure 4 shows the changes in spreads: it presents the pooled data from the three episodes, as well as the data for each individual event. Each subplot shows the change in CDS spreads (on the vertical axis), plotted against the ratio of domestic (or external) liabilities to reserves during the previous month (on the horizontal axis). If a higher level of domestic liabilities to reserves

\footnotetext{
${ }^{25}$ For this exercise we use CDS spread data which is readily available at a daily frequency.

${ }^{26}$ In two of the episodes there are two dates in which the conditions hold but less than 10 days apart, in these cases we consider the earliest of the two dates.
} 
reduces the spread, we should expect the curve to have a negative slope. If a higher level of external liabilities increases the spread, we should expect the curve to have a positive slope. The coefficients of the OLS regressions are reported in Table 7.

Let's first consider the pooled data for the three episodes. The first row in Figure 4 and in Table 7 show that spreads behave differently depending on how reserves have been financed. As can be seen in the first row of Figure 4, a higher share of domestic currency denominated liabilities tends to reduce the impact on spreads. The opposite occurs if reserves are mostly financed with external liabilities. The first row of Table 7 shows the value of the coefficients and a test of their equality. Not only the signs are as expected, but also the hypothesis that both coefficients are equal can be strongly rejected.

The remainder of Figure 4 and Table 7 shows the data for the three individual events. As can be seen, the coefficients are as expected, and in two of the three cases the hypothesis of equality of coefficients can be rejected. ${ }^{27}$

Table 7: Regression results. Exogenous shocks.

\begin{tabular}{lccc}
\hline \hline & \multicolumn{2}{c}{ Dependent variable: Spread Variation } \\
& Domestic Liabilities & External Liabilities & p-value difference \\
\hline Pooled & $-39.80^{* *}$ & 155.00 & $0.06^{*}$ \\
& $(19.70)$ & $(100.00)$ & \\
First Event & $-37.60^{* * *}$ & 45.10 & $0.00^{* * *}$ \\
& $(9.70)$ & $(28.00)$ & $0.00^{* * *}$ \\
Second Event & $-58.00^{* *}$ & $208.00^{* * *}$ & \\
& $(27.40)$ & $(37.30)$ & 0.24 \\
Third Event & -22.30 & 180.00 & \\
\hline \hline
\end{tabular}

Note: Robust standard errors in parentheses. ${ }^{*} \mathrm{p}<0.1 ;{ }^{* *} \mathrm{p}<0.05 ;{ }^{* * *} \mathrm{p}<0.01$

\footnotetext{
${ }^{27} \mathrm{As}$ can be seen, in the third event there is one outlier. The pooled results (and obviously the results for the first and second events) do not hinge on this observation. Results removing these outlier are presented in Table C.10 of Appendix C.
} 


\section{Pooled}
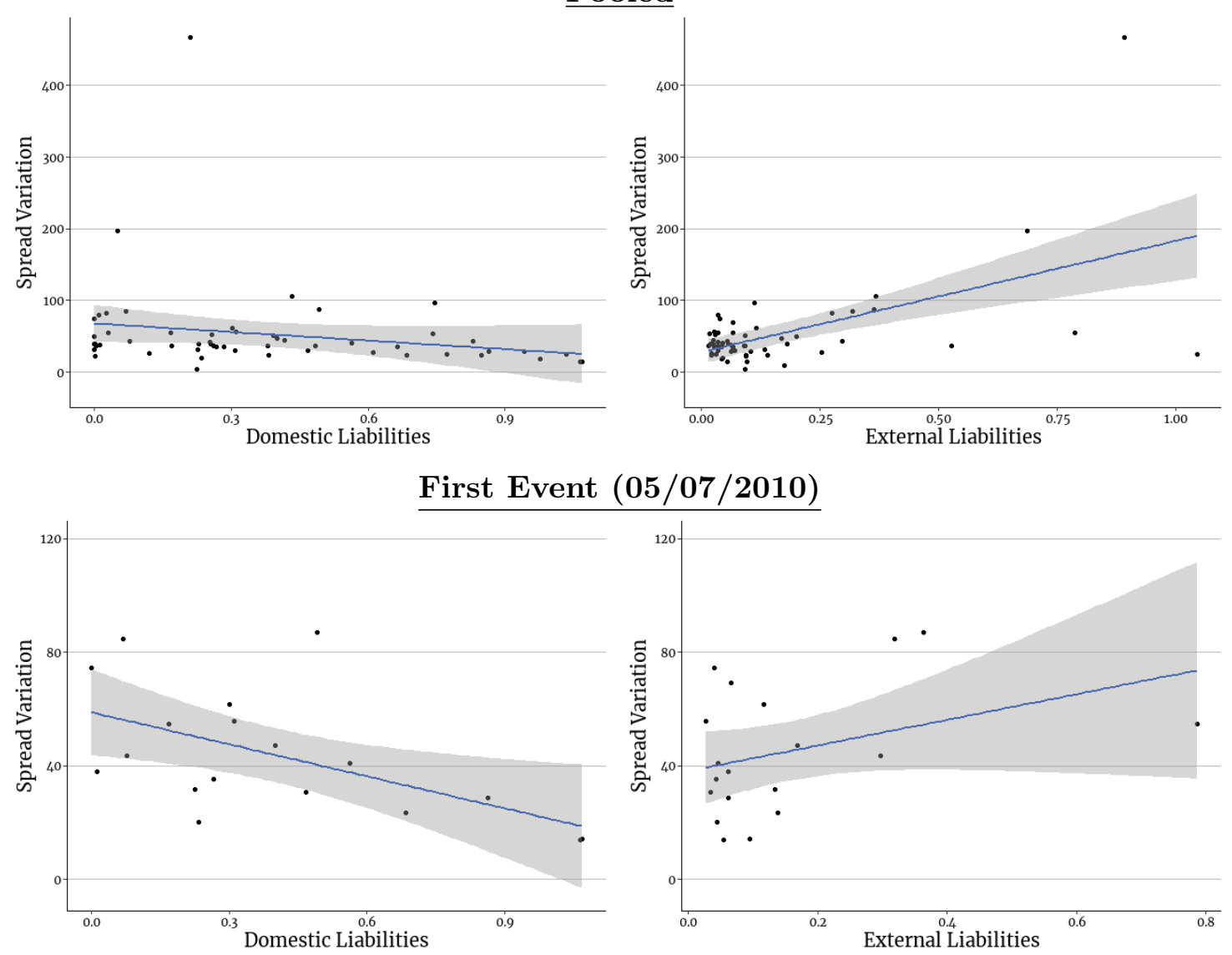

$(05 / 07 / 2010)$

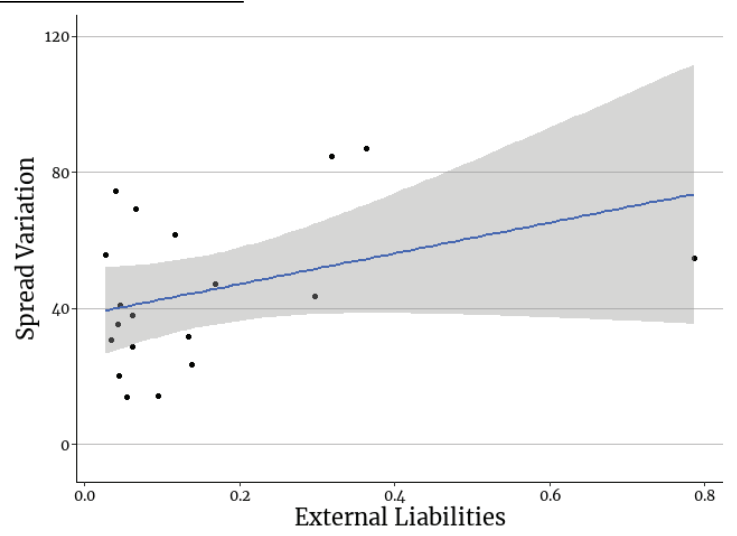

Second Event (08/08/2011)
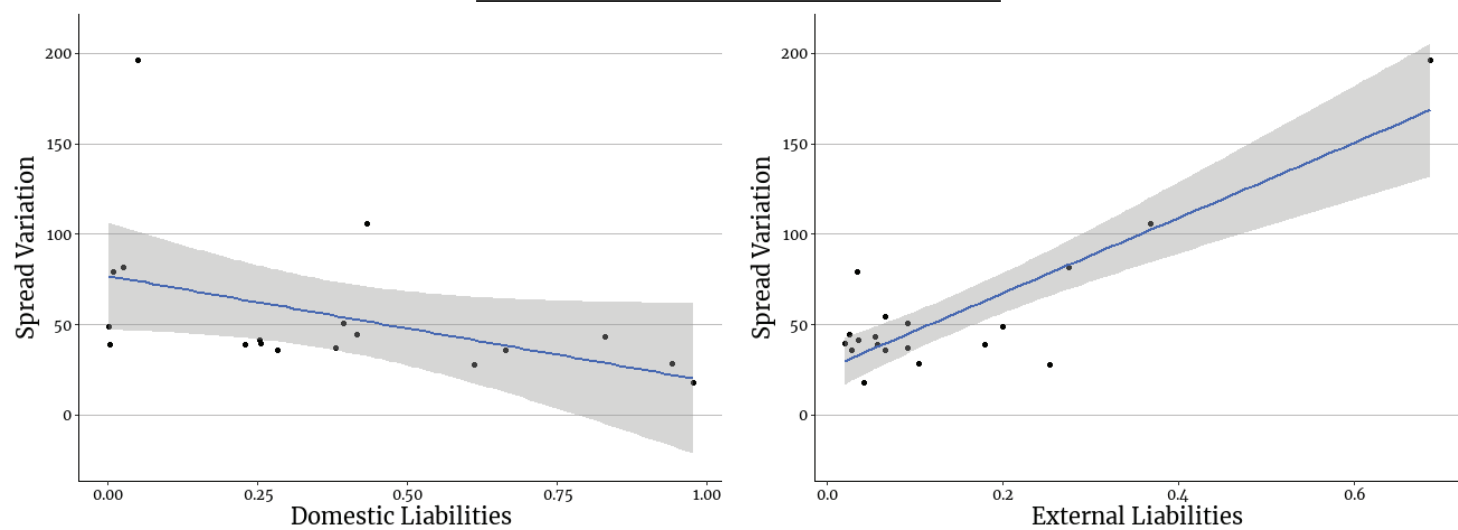

Third Event $(08 / 24 / 2015)$
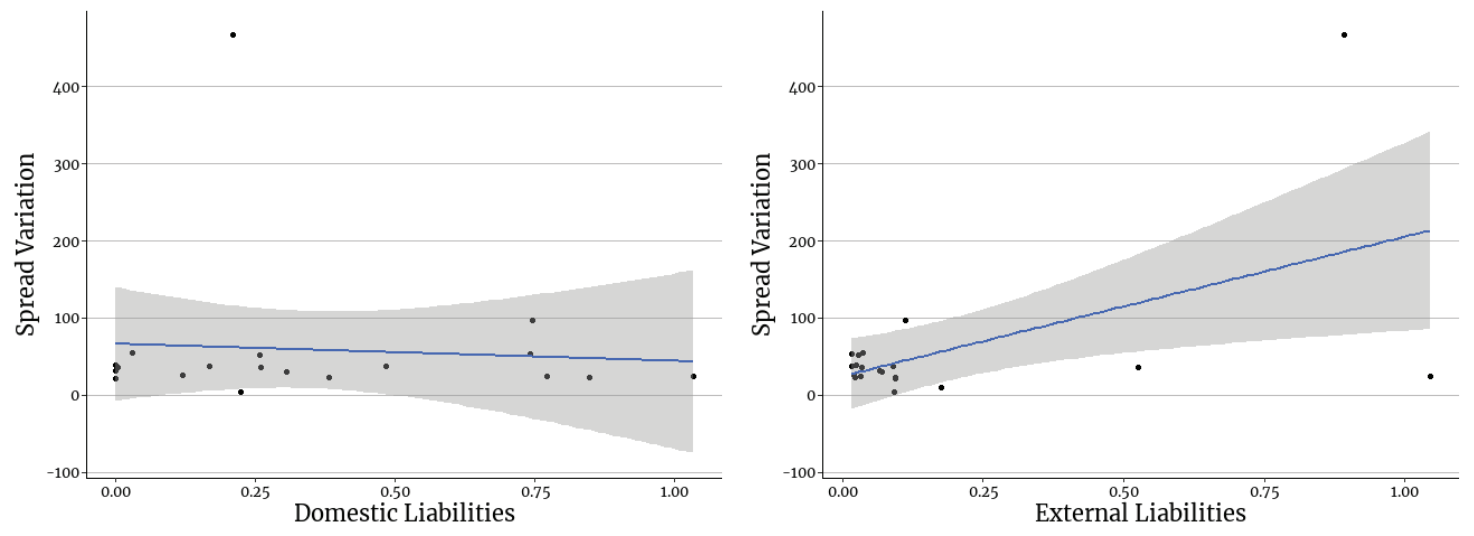

Figure 4: Events Studies for Domestic and External Liabilities. 


\section{Extensions/Robustness}

In this section we implement two extensions to assess the robustness of our results. First, we extend our theory and empirical work to study the extent to which allowing for private debt (either state contingent or not) matters for our findings. We show that our main result, that financing reserves with state-contingent sovereign debt helps decrease spreads, is robust to this extension. Second, we explore whether the different ways in which the country finances its reserves buildup has and effect on other measures of crisis risk, beyond the sovereign spread. For this, we use Goldman Sachs' Financial Conditions Index and find results pointing in the same direction: higher reserves alleviate the degree of financial stress but only the extent that they are financed with domestic liabilities.

\subsection{The role of private debt}

Model extension. In this section we extend our baseline model to allow for a productive private sector that also needs to borrow (from foreign lenders). The inclusion of a private sector which faces borrowing costs affected by the sovereign risk implies that the portfolio choice of the government can stabilize or destabilize aggregate output. Within this richer framework we analyze the main result of our paper, that spreads are lower when the government uses contingent debt, and find that it holds both in the presence of the private sector and regardless of whether this sector finances itself with either non contingent or contingent debt.

The extended model features a small open economy populated by three agents: households, firms and a benevolent government. The households supply labor and consume (but are otherwise static - have no direct savings decision). The firms produce the consumption good using labor and face a working capital constraint: they need to pay a fraction of their wage bill upfront and therefore need to borrow to finance this. That borrowing is intra-period and vis-a-vis international lenders. As mentioned before, the rate paid by the firms is a function of the governments default risk: as the default probability increases, the firms face more expensive borrowing costs, other things equal. If the sovereign defaults, and looses access to foreign borrowing, we assume that firms' borrowing costs experience a discrete increase. Finally, the government is benevolent and chooses debt, reserves, (lump-sum) taxes, and whether to default. We allow both private and public borrowing to be indexed to the state of the economy. This small open economy trades bonds with a large mass of international lenders. These lenders are modelled identically to the baseline model in section 2. 
A full description of this extended model is relegated to Appendix B. In the appendix we spell out the actions of each agent, the recursive problem of the government, and solve the model quantitatively (with the corresponding recalibration). ${ }^{28}$

The main take-away is that our headline result, namely that financing reserves with statecontingent sovereign debt reduces spreads, is robust to the introduction of a production economy with the possibility of indexed private debt. In particular, Figure 5 shows that the main testable implication of our theory is robust to different degrees of firm debt indexation. Namely, for a given level of debt, financing reserve accumulation with contingent government debt (in particular, using an instrument indexed to the performance of domestic income) allows the country to pay lower spreads than it would otherwise (i.e., had it used non-state contingent debt instead), and this holds irrespective of whether the private sector is borrowing with non contingent or contingent debt.
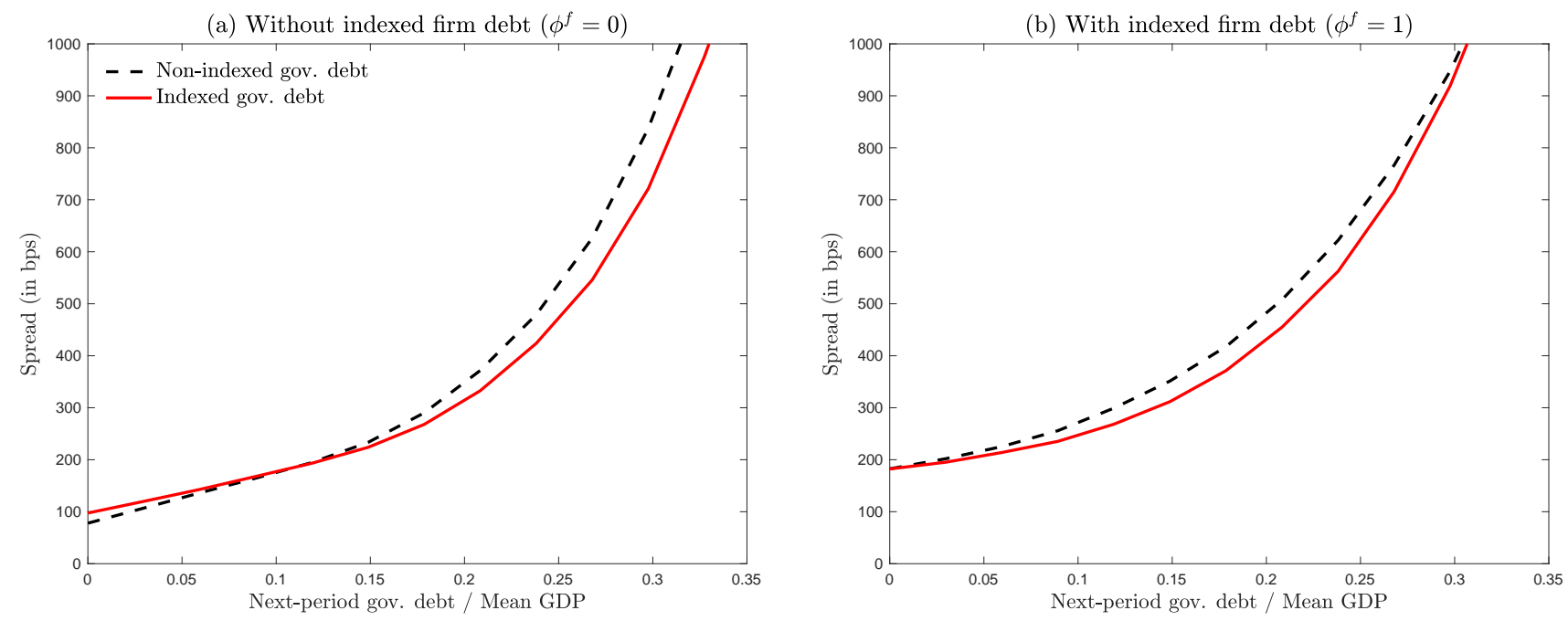

Figure 5: Spread-debt menus and debt indexation in a production economy

Note: The figure is computed for the mean income and the mean reserve levels in the simulations of the benchmark model with production (i.e. without debt indexation neither public nor private), and assuming no risk-premium shock in the current period $\left(\omega_{t}=0\right)$.

Taking the extended model to the data. Table 8 provides the results obtained from adding the currency composition of private debt to our estimates. The private debt currency composition data is taken from the BIS. ${ }^{29}$ It measures the share of foreign currency debt issued by non financial corporations. The data is quarterly and is transformed to monthly data using splines.

As shown in Table 3, our main specification already included a control for the level of private

\footnotetext{
${ }^{28}$ Moreover, as we explain in footnote 33 of Appendix B, one can re-parametrize the extended model in such a way as to recover the endowment economy framework we have in Section 2.

${ }^{29}$ See https://www.bis.org/statistics/secstats.htm? $\mathrm{m}=2615$.
} 
debt. In this section we go further and find that, in line with the prediction of the extended model, the currency composition of the private debt has no effect on the main result. For brevity Table 8 only shows the coefficient of the effect of reserves and of the private debt currency composition, with the complete table presented in Appendix C.11.

Table 8: Adding the currency composition of private debt

\begin{tabular}{|c|c|c|c|c|c|c|c|c|}
\hline & \multicolumn{8}{|c|}{ Dependent variable: log(spread) } \\
\hline & $(1)$ & $(2)$ & $(3)$ & $(4)$ & $(5)$ & $(6)$ & $(7)$ & $(8)$ \\
\hline Reserve Ratio & $\begin{array}{c}-2.58^{* * *} \\
(0.11)\end{array}$ & $\begin{array}{c}-2.76^{* * *} \\
(0.55)\end{array}$ & $\begin{array}{l}-1.51 \\
(1.20)\end{array}$ & $\begin{array}{c}-3.30^{* * *} \\
(0.61)\end{array}$ & $\begin{array}{c}-2.28^{* * *} \\
(0.55)\end{array}$ & $\begin{array}{l}-1.24 \\
(1.18)\end{array}$ & $\begin{array}{c}-2.90^{* * *} \\
(0.69)\end{array}$ & $\begin{array}{c}-1.98^{* * *} \\
(0.64)\end{array}$ \\
\hline $\begin{array}{l}\text { Private Debt } \\
\text { Currency Comp. }\end{array}$ & & & $\begin{array}{c}0.29 \\
(0.21)\end{array}$ & $\begin{array}{c}0.29 \\
(0.20)\end{array}$ & $\begin{array}{c}0.29 \\
(0.19)\end{array}$ & $\begin{array}{c}0.20 \\
(0.18)\end{array}$ & $\begin{array}{c}0.21 \\
(0.18)\end{array}$ & $\begin{array}{c}0.20 \\
(0.18)\end{array}$ \\
\hline Fixed effects? & No & Yes & Yes & Yes & Yes & Yes & Yes & Yes \\
\hline Year dummies? & No & No & No & No & No & Yes & Yes & Yes \\
\hline Observations & 4,497 & 4,497 & 3,150 & 3,150 & 3,150 & 3,150 & 3,150 & 3,150 \\
\hline $\mathrm{R}^{2}$ & 0.52 & 0.57 & 0.70 & 0.71 & 0.70 & 0.73 & 0.74 & 0.74 \\
\hline Adjusted $\mathrm{R}^{2}$ & 0.52 & 0.57 & 0.70 & 0.70 & 0.70 & 0.73 & 0.73 & 0.73 \\
\hline
\end{tabular}

\subsection{Effects on other variables}

While our paper has modeled and tested the effect on how reserves are accumulated on sovereign spreads, it begs the question of how much this result extends to other macroeconomic variables. Such testing, because of endogeneity issues, is beyond the scope of this paper. However, in order to explore if the results extend beyond just sovereign spreads and are relevant, for example, as predictors of future financial crises, we replicate our estimates of Table 3, but replacing our dependent variable for the Goldman Sach's financial conditions index. This Goldman Sachs's index is constructed as a weighted average of country interest rates, the exchange rate, equity valuations, and credit spreads, with weights that correspond to the direct impact of each variable on GDP. A higher value of this variable indicates a higher degree of financial stress in a given country. The broader scope of this variable makes it a good testing ground for the mechanism described in the paper. ${ }^{30}$

\footnotetext{
${ }^{30}$ We thank Alberto Ramos of Goldman Sachs for making this data accessible to us. See https://www.goldmansachs.com/insights/pages/case-for-financial-conditions/report-the-case-for-financialconditions-index.pdf for a description of the index.
} 
Table 9: The Effect on Financial Conditions

\begin{tabular}{|c|c|c|c|c|c|c|c|c|}
\hline & \multicolumn{8}{|c|}{ Dependent variable: Financial Conditions } \\
\hline & (1) & $(2)$ & $(3)$ & $(4)$ & $(5)$ & (6) & $(7)$ & $(8)$ \\
\hline Risk Aversion & $\begin{array}{c}1.32^{* * *} \\
(0.18)\end{array}$ & $\begin{array}{l}1.10^{* *} \\
(0.43)\end{array}$ & $\begin{array}{c}1.32^{* * *} \\
(0.44)\end{array}$ & $\begin{array}{c}1.32^{* * *} \\
(0.46)\end{array}$ & $\begin{array}{c}1.26^{* * *} \\
(0.43)\end{array}$ & $\begin{array}{c}2.76^{* * *} \\
(0.93)\end{array}$ & $\begin{array}{c}2.81^{* * *} \\
(0.96)\end{array}$ & $\begin{array}{c}2.77^{* * *} \\
(0.94)\end{array}$ \\
\hline Rating & $\begin{array}{c}2.25^{* * *} \\
(0.69)\end{array}$ & $\begin{array}{l}-0.67 \\
(7.77)\end{array}$ & $\begin{array}{l}-2.97 \\
(8.40)\end{array}$ & $\begin{array}{l}-2.42 \\
(8.09)\end{array}$ & $\begin{array}{l}-2.62 \\
(8.21)\end{array}$ & $\begin{array}{c}0.12 \\
(7.36)\end{array}$ & $\begin{array}{l}-0.15 \\
(7.36)\end{array}$ & $\begin{array}{l}-0.08 \\
(7.47)\end{array}$ \\
\hline World Rate & $\begin{array}{c}2.85^{* * *} \\
(0.23)\end{array}$ & $\begin{array}{l}1.88^{* *} \\
(0.77)\end{array}$ & $\begin{array}{l}1.26^{*} \\
(0.68)\end{array}$ & $\begin{array}{c}1.07 \\
(0.74)\end{array}$ & $\begin{array}{l}1.07 \\
(0.73)\end{array}$ & $\begin{array}{c}2.17^{* * *} \\
(0.69)\end{array}$ & $\begin{array}{c}2.18^{* * *} \\
(0.68)\end{array}$ & $\begin{array}{c}2.17^{* * *} \\
(0.68)\end{array}$ \\
\hline Reserve Ratio & $\begin{array}{c}-3.32^{* * *} \\
(0.85)\end{array}$ & $\begin{array}{c}-16.60^{* *} \\
(8.00)\end{array}$ & $\begin{array}{c}14.30 \\
(21.40)\end{array}$ & $\begin{array}{c}-19.90^{* * *} \\
(3.33)\end{array}$ & $\begin{array}{c}-0.34 \\
(11.80)\end{array}$ & $\begin{array}{c}2.79 \\
(12.40)\end{array}$ & $\begin{array}{c}-7.41^{* *} \\
(3.36)\end{array}$ & $\begin{array}{c}1.41 \\
(11.60)\end{array}$ \\
\hline Sovereign Debt & $\begin{array}{c}8.58^{* * *} \\
(0.85)\end{array}$ & $\begin{array}{l}1.01 \\
(9.57)\end{array}$ & $\begin{array}{c}0.84 \\
(10.70)\end{array}$ & $\begin{array}{c}-0.53 \\
(11.00)\end{array}$ & $\begin{array}{c}-1.04 \\
(11.00)\end{array}$ & $\begin{array}{c}-3.21 \\
(10.20)\end{array}$ & $\begin{array}{c}-3.97 \\
(10.50)\end{array}$ & $\begin{array}{c}-4.36 \\
(10.50)\end{array}$ \\
\hline Private Debt & $\begin{array}{c}6.90^{* * *} \\
(0.93)\end{array}$ & $\begin{array}{c}18.00 \\
(11.90)\end{array}$ & $\begin{array}{c}20.40^{* *} \\
(9.43)\end{array}$ & $\begin{array}{c}18.70^{* *} \\
(9.30)\end{array}$ & $\begin{array}{c}20.10^{* *} \\
(9.58)\end{array}$ & $\begin{array}{c}14.60 \\
(11.50)\end{array}$ & $\begin{array}{c}13.70 \\
(11.40)\end{array}$ & $\begin{array}{c}14.50 \\
(11.70)\end{array}$ \\
\hline $\begin{array}{l}\text { Remunerated } \\
\text { Domestic Liabilities }\end{array}$ & & & $\begin{array}{l}-33.80^{*} \\
(20.30)\end{array}$ & & $\begin{array}{l}-18.10 \\
(11.80)\end{array}$ & $\begin{array}{c}-8.73 \\
(10.10)\end{array}$ & & $\begin{array}{l}-7.49 \\
(10.90)\end{array}$ \\
\hline $\begin{array}{l}\text { Unsterilized } \\
\text { Purchases }\end{array}$ & & & $\begin{array}{l}-13.80 \\
(19.20)\end{array}$ & $\begin{array}{c}22.50 \\
(14.50)\end{array}$ & & $\begin{array}{c}-0.29 \\
(14.30)\end{array}$ & $\begin{array}{c}10.90 \\
(13.20)\end{array}$ & \\
\hline $\begin{array}{l}\text { Others } \\
\text { Balance Sheet }\end{array}$ & & & $\begin{array}{c}-52.40^{* * *} \\
(20.30)\end{array}$ & $\begin{array}{l}-16.50 \\
(10.70)\end{array}$ & $\begin{array}{c}-35.90^{* *} \\
(15.60)\end{array}$ & $\begin{array}{c}-12.10 \\
(8.23)\end{array}$ & $\begin{array}{l}-3.59 \\
(7.06)\end{array}$ & $\begin{array}{l}-11.50 \\
(13.70)\end{array}$ \\
\hline External Liabilities & & & & $\begin{array}{l}48.50^{*} \\
(24.90)\end{array}$ & $\begin{array}{l}28.10^{*} \\
(15.90)\end{array}$ & & $\begin{array}{c}22.20 \\
(16.70)\end{array}$ & $\begin{array}{l}12.00 \\
(8.74)\end{array}$ \\
\hline Constant & $\begin{array}{c}81.00^{* * *} \\
(2.61)\end{array}$ & & & & & & & \\
\hline Fixed effects? & No & Yes & Yes & Yes & Yes & Yes & Yes & Yes \\
\hline Year dummies? & No & No & No & No & No & Yes & Yes & Yes \\
\hline Observations & 1,248 & 1,248 & 1,248 & 1,248 & 1,248 & 1,248 & 1,248 & 1,248 \\
\hline Adjusted $\mathrm{R}^{2}$ & 0.25 & 0.29 & 0.35 & 0.37 & 0.36 & 0.50 & 0.50 & 0.50 \\
\hline
\end{tabular}


The effect on the financial conditions index is computed in Table 9 that shows that higher reserves alleviate the degree of financial stress but only to the extent that they are financed with (remunerated) domestic liabilities, while accumulating reserves with foreign liabilities continues to deteriorate financial conditions (as was the case with the sovereign spread). Notice that the effect on this broader macroeconomic measure, weakens when reserves are accumulated with unsterilized purchases (relative to our findings when studying sovereign spreads). We find this result intuitive. Accumulating reserves with unsterilized purchases may create a larger collateral damage to the economy (for example higher inflation) which does not occur when reserves are purchased with domestic liabilities (which is purely a hedge against negative shocks).

\section{Concluding remarks}

In a nutshell this paper addresses the simple but specific question of whether the way a central bank finances its reserves matters for country spreads. This specific question is motivated by the broader question of whether the way reserve accumulation is financed matters for a larger set of macroeconomic variables.

The link relating the way reserves are accumulated to sovereign spreads is a natural starting point. Accumulating reserves with dollar debt (i.e., assets and liabilities with the same denomination), while providing liquidity in foreign currency, does not provide any hedge in times of distress. Domestic debt (either denominated in local currency or indexed to domestic outcomes), on the other hand, provides both hedge and liquidity, thus affecting the possibility of default and thus impacting directly on sovereign spreads.

This paper contributes in several ways to the literature. First, it provides a general model to explain why the form of reserve accumulation matters. Accumulating reserves with state contingent debt, that reduces the financing needs in times of distress, lowers the risk of default and leads to lower spreads (for a given level of debt). Secondly, we show these effects are found in the data. We show that accumulating reserves with domestic currency denominated liabilities does reduce spreads while using external liabilities does not. These results have been mostly absent from the literature even when they have relevant implications for policy makers.

For example, since reserves accumulated through increasing external liabilities are shown to have a relatively minor effect on country spreads, this means that programs of reserve buildup, as typically laid out in IMF programs (financed in dollars or SDRs), may have limited effects on country risk. Given that the issuance of domestic currency denominated liabilities seems to be 
more beneficial, our results suggest that, to the extent that foreign investors can diversify country specific risks (as multilaterals may be able to do), the instruments used for such programs can be improved upon by offering financing schemes that more closely resemble contingent debt. It may be argued that conditionality and renegotiation fulfill that role, but this does not belittle the importance of finding better debt instruments.

Of course, the variables that may be affected by the way reserves are accumulated go beyond sovereign spreads. Our results in section 4 showing that the way reserves are accumulated affects crisis indicators such as Goldman Sachs' financial conditions index, suggest that such an effect may be present in the data. The probability of a sudden stop is another obvious candidate to analyze. Given that the literature has been relatively silent about the form of financing of reserves, we hope that this work, though it focuses on spreads, motivates the exploration of this relationship for other variables.

\section{References}

Acharya, Viral and Arvind Krishnamurthy, "Capital flow management with multiple instruments," Series on Central Banking Analysis and Economic Policies no. 26, 2019.

Aguiar, Mark and Gita Gopinath, "Emerging markets business cycles: the cycle is the trend," Journal of Political Economy, 2007, 115 (1), 69-102.

Aizenman, Joshua and Daniel Riera-Crichton, "Real exchange rate and international reserves in an era of growing financial and trade integration," The Review of Economics and Statistics, 2008, 90 (4), 812-815.

_ and Jaewoo Lee, "International reserves: precautionary versus mercantilist views, theory and evidence," Open Economies Review, 2007, 18 (2), 191-214.

Alfaro, Laura and Fabio Kanczuk, "Optimal reserve management and sovereign debt," Journal of International Economics, 2009, 77 (1), 23-36.

_ and _, "Debt redemption and reserve accumulation," IMF Economic Review, 2019, 67 (2), $261-287$.

Arce, Fernando, Julien Bengui, and Javier Bianchi, "A macroprudential theory of foreign reserve accumulation," 2019. NBER Working Paper No. 26236.

Arellano, Cristina and Ananth Ramanarayanan, "Default and the maturity structure in sovereign bonds," Journal of Political Economy, 2012, 120 (2), 187-232. 
Benigno, G., L. Fornaro, and M. Wolf, "Reserve Accumulation, Growth and Financial Crisis," 2021. Mimeo, Centre for Economic Performance, LSE.

Bertinatto, Lucas Pablo, David Gomtsyan, Guido Sandleris, Horacio Sapriza, Filippo Taddei et al., "Indexed sovereign debt: An applied framework," The Carlo Alberto Notebooks, 2017, 104 .

Bianchi, Javier and César Sosa-Padilla, "Reserve Accumulation, Macroeconomic Stabilization, and Sovereign Risk," 2020. NBER Working Paper 27323.

_ , Juan Carlos Hatchondo, and Leonardo Martinez, "International reserves and rollover risk," American Economic Review, 2018, 108 (9), 2629-2670.

Bocola, Luigi and Guido Lorenzoni, "Financial crises, dollarization, and lending of last resort in open economies," 2017. NBER Working Paper No. 23266.

Bussière, Matthieu, Gong Cheng, Menzie D Chinn, and Noëmie Lisack, "For a few dollars more: Reserves and growth in times of crises," Journal of International Money and Finance, 2015, 52, 127-145.

Caballero, Ricardo J and Stavros Panageas, "Hedging sudden stops \& precautionary recessions: a quantitative framework," 2003. Cambridge, MA: Massachusetts Institute of Technology, Dept. of Economics.

Calvo, Guillermo A, Alejandro Izquierdo, and Rudy Loo-Kung, "Optimal holdings of international reserves: Self-insurance against sudden stops," Monetaria (CEMLA), 2013, 1 (1).

Cartas, Jose and Artak Harutyunyan, Monetary and financial statistics manual and compilation guide, International Monetary Fund, 2017.

Céspedes, Luis Felipe and Roberto Chang, "Optimal Foreign Reserves and Central Bank Policy Under Financial Stress," 2019. NBER Working Paper 27923.

Chatterjee, Satyajit and Burcu Eyigungor, "Maturity, indebtedness, and default risk," American Economic Review, 2012, 102 (6), 2674-2699.

Dellas, H and Ch. Yoo, "Reserve currency preferences of central banks.," Journal of International Money and Finance, 1991, 10, 406-419.

Dominguez, Kathryn ME, Yuko Hashimoto, and Takatoshi Ito, "International reserves and the global financial crisis," Journal of International Economics, 2012, 88 (2), 388-406.

Durdu, Ceyhun Bora, "Quantitative implications of indexed bonds in small open economies," Journal of Economic Dynamics \& Control, 2009, 33, 883-902.

Forbes, Kristin and Francis Warnock, "Capital flow waves: surges, stops, flight, and retrenchment," Journal of International Economics, 2012, 88 (2), 235-251.

Greenspan, Alan, "Currency reserves and debt," in "Remarks before the World Bank Conference on Recent Trends in Reserves Management, Washington, DC," Vol. 291999. 
Hatchondo, Juan Carlos and Leonardo Martinez, "Long-duration bonds and sovereign defaults," Journal of International Economics, 2009, 79 (1), 117-125.

_ and _ , "On the benefits of GDP-indexed government debt: lessons from a model of sovereign defaults," FRB Richmond Economic Quarterly, 2012, 98 (2), 139-157.

_ , , and César Sosa-Padilla, "Debt dilution and sovereign default risk," Journal of Political Economy, 2016, 124 (5), 1383-1422.

_ , _ , and Horacio Sapriza, "Quantitative properties of sovereign default models: Solution methods matter," Review of Economic Dynamics, 2010, 13 (4), 919-933.

_ , _, and Yasin Kürşat Önder, "Non-defaultable debt and sovereign risk," 2014. IMF Working Paper 14/198.

Hur, Sewon, César Sosa-Padilla, and Zeynep Yom, "Optimal bailouts in banking and sovereign crises," 2022.

IMF, “Assessing Reserve Adequacy," IMF Policy Papers, 2011.

Jeanne, Olivier and Romain Ranciere, "The optimal level of international reserves for emerging market countries: A new formula and some applications," Economic Journal, 2011, 121(555), 905-930.

Johri, Alok, Shahed Khan, and César Sosa-Padilla, "Interest Rate Uncertainty and Sovereign Default Risk," 2020. NBER Working Paper 27639.

Levy-Yeyati, Eduardo, "Financial dollarization: evaluating the consequences," Economic Policy, 2006, 21 (45), 62-118.

_ , "The cost of reserves," Economics Letters, 2008, 100 (1), 39-42.

- and Juan Francisco Gómez, "The cost of holding foreign exchange reserves," in "Asset Management at Central Banks and Monetary Authorities," Springer, 2020, pp. 91-110.

Longstaff, Francis A., Jun Pan, Lasse H. Pedersen, and Kenneth J. Singleton, "How sovereign is sovereign credit risk?," American Economic Journal: Macroeconomics, 2011, 3 (2), 75-103.

Neumeyer, Pablo A. and Fabrizio Perri, "Business cycles in emerging economies: The role of interest rates," Journal of Monetary Economics, 2005, 52(2), 345-380.

Orazi, Pablo, Mario Torriani, and Matias Vicens, "Strategic Asset Allocation of a Reserves' Portfolio: Hedging against Shocks," Central Bank of Argentina, Economic Research Department, 2020. Working Paper No. 88.

Rey, Hélène, "Dilemma not trilemma: the global cycle and monetary policy independence," Proceedings - Economic Policy Symposium - Jackson Hole, 2013.

Roch, Francisco and Francisco Roldan, "Uncertainty Premia, Sovereign Default Risk, and State-Contingent Debt," 2021. IMF Working Paper 21/76. 
Rodrik, Dani, "The social cost of foreign exchange reserves," International Economic Journal, 2006, 20 (3), 253-266.

_ and Andres Velasco, "Short-term capital flows," 1999. NBER Working Paper No. 7364.

Samano, Agustin, "International Reserves and Central Bank Independence," Mimeo, 2021.

Sosa-Padilla, César, "Sovereign defaults and banking crises," Journal of Monetary Economics, 2018, 99, 88-105.

Sturzenegger, Federico, "Tools for the Analysis of Debt Problems," Journal of Reconstructing Finance, 2004, 1 (1), 201-223.

_, "Reserve Management: A Governor's Eye View," HSBC Reserve Management Trends 2019, Central Bank Publications, 2019.

_ , "Macri's Macro: The Elusive Road to Stability and Growth," Brookings Papers of Economic Activity, 2020, (135), 339-411.

- and Jeromin Zettelmeyer, Debt Defaults and Lessons from a Decade of Crises, Cambridge and London: MIT Press, 2006.

Uribe, Martín and Vivian Z. Yue, "Country spreads and emerging countries: Who drives whom?," Journal of International Economics, 2006, 69 (1), 6-36.

Vasicek, Oldrich, "An equilibrium characterization of the term structure," Journal of Financial Economics, 1977, 5 (2), 177-188. 


\section{Appendices}

\section{A Data appendix}

Table A.1: Summary Statistics of Selected Variables

\begin{tabular}{lcccccc}
\hline \hline Statistic & $\mathrm{N}$ & Mean & St. Dev. & Min & Median & Max \\
\hline Sovereign spread & 4,497 & 409.83 & 334.41 & 21.20 & 321.77 & 3,863 \\
Credit Rating & 4,497 & 16.38 & 3.46 & 1 & 16 & 21 \\
Reserves Ratio & 4,497 & 0.15 & 0.08 & 0.0004 & 0.13 & 0.47 \\
Sovereign Debt Ratio & 4,497 & 0.23 & 0.15 & 0.01 & 0.19 & 0.83 \\
Private Debt & 4,497 & 0.13 & 0.16 & 0.00 & 0.08 & 0.96 \\
Risk Aversion & 4,497 & 573.48 & 286.38 & 257.14 & 488.91 & $2,030.95$ \\
10 Year US Treasury & 4,497 & 3.11 & 1.02 & 1.50 & 2.89 & 5.39 \\
Unsterilized Purchases & 4,497 & 0.10 & 0.09 & -0.14 & 0.09 & 0.41 \\
External Liabilities Ratio & 4,497 & 0.02 & 0.03 & 0.0 & 0.01 & 0.16 \\
Remunerated Liabilities Ratio & 4,497 & 0.04 & 0.05 & 0.0 & 0.02 & 0.23 \\
Priv. Debt currency comp. & 3,150 & 0.07 & 0.16 & 0.00 & 0.00 & 1.00 \\
Financial Conditions & 1,248 & 100.00 & 2.33 & 94.20 & 100.00 & 110.00 \\
\hline \hline
\end{tabular}

Table A.2: Countries in the Sample

\begin{tabular}{cc}
\hline \hline Algeria & Mexico \\
Belarus & Morocco \\
Belize & Nigeria \\
Brazil & Pakistan \\
Bulgaria & Peru \\
Colombia & Philippines \\
Ivory Coast & Russian Federation \\
Dominican Republic & Senegal \\
Egypt & South Africa \\
Georgia & Sri Lanka \\
Ghana & Thailand \\
Indonesia & Tunisia \\
Jamaica & Turkey \\
Jordan & Ukraine \\
Kazakhstan & Venezuela \\
\hline \hline
\end{tabular}


Table A.3: Variables and Sources

\begin{tabular}{|c|c|c|}
\hline Name & Description & Source \\
\hline Sovereign Spread & $\begin{array}{l}\text { JP Morgan EMBI global } \\
\text { index blended spread, in bps }\end{array}$ & The World Bank \\
\hline Risk aversion & $\begin{array}{l}\text { Merrill Lynch ICE BofAML } \\
\text { Option-Adjusted Spreads }\end{array}$ & FRED \\
\hline World Rate & $\begin{array}{l}\text { US Treasury notes, } 10 \text { year } \\
\text { constant maturity yield, bps }\end{array}$ & FRED \\
\hline Credit rating & $\begin{array}{l}\text { S\&P rating, long term debt, } \\
\text { end of period, foreign currency } \\
\text { We construct an index starting in } \\
1 \text { at Not Rated (NR) } \\
\text { up to the top in } 29 \text { at "AAA". }\end{array}$ & Standard \& Poor's \\
\hline Sovereign Debt & $\begin{array}{l}\text { Public and publicly guaranteed } \\
\text { debt from private creditors }\end{array}$ & $\begin{array}{l}\text { The World Bank's, } \\
\text { International Debt Statistics (IDS) }\end{array}$ \\
\hline Private Debt & $\begin{array}{l}\text { External debt stock's, } \\
\text { private nonguaranteed }\end{array}$ & $\begin{array}{l}\text { The World Bank's } \\
\text {,International Debt Statistics (IDS) }\end{array}$ \\
\hline GDP & GDP, current US dollars & The World Bank \\
\hline Reserves Ratio & Claims on non residents & IFS \\
\hline $\begin{array}{l}\text { Remunerated } \\
\text { Domestic Liabilities }\end{array}$ & & IFS \\
\hline $\begin{array}{l}\text { Unsterilized } \\
\text { Purchases }\end{array}$ & & IFS \\
\hline External Liabilities & & IFS \\
\hline Fiscal Balance & Primary net lending/borrowing & $\begin{array}{c}\text { IMF } \\
(\text { GGXONLB_G01_GDP_PT) }\end{array}$ \\
\hline Dollarization & Deposits in dollars (as \% of total deposits) & (Levy-Yeyati, 2006) \\
\hline $\begin{array}{l}\text { Private debt } \\
\text { currency composition }\end{array}$ & $\begin{array}{l}\text { Share of non-financial corporate debt } \\
\text { denominated in foreign currency }\end{array}$ & BIS \\
\hline Financial conditions & & Goldman Sachs \\
\hline
\end{tabular}




\section{B Model extension: allowing for private borrowing}

In this appendix we extend our baseline model to for a productive private sector that also needs to borrow (from foreign lenders). We show that are main result is robust to this extension: we still find that the way in which the government finances its reserves matters for the country spreads. In particular, whether the private sector borrows from abroad, and whether it does it with state or non-state contingent instruments does not affect the main finding: accumulating reserves with sovereign state contingent debt that reduces the financing needs in times of distress and lowers the risk of default leads to lower sovereign spreads (for a given level of debt).

\section{B.1 Environment}

Consider a small open economy populated by three agents: households, firms and a benevolent government. The households supply labor and consume (but are otherwise static - have no direct savings decision). The firms produce the consumption good using labor and face a working capital constraint: they need to pay a fraction of their wage bill upfront and therefore need to borrow to finance this. That borrowing is intra-period and vis-a-vis international lenders. Finally, the government is benevolent and chooses debt, reserves, (lump-sum) taxes, and default. We allow both private and public borrowing to be indexed to the state of the economy.

Households. The only decisions of the households involve the labor supply and consumption levels. Therefore, the problem faced by the households can be expressed as:

$$
\begin{aligned}
\max _{\{c, n\}} & U(c, n) \\
\text { s.t. } & c=w n+\Pi^{F}-T,
\end{aligned}
$$

where $U(c, n)$ is the period utility function, $c$ stands for consumption, $n$ denotes labor supply, $w$ is the wage rate, $T$ is a lump-sum tax, and $\Pi^{F}$ represents the firms' profits. The solution to this problem requires:

$$
-\frac{U_{n}}{U_{c}}=w
$$

which is the usual intratemporal optimality condition equating the marginal rate of substitution between leisure and consumption to the real wage rate. In what follows we assume that

$$
U(c, n)=\frac{\left(c-\chi \frac{n^{\nu}}{\nu}\right)^{1-\gamma}}{1-\gamma}
$$

where $\chi$ is a scaling parameter affecting the labor disutility, $\gamma$ governs the risk aversion, and $\nu$ governs the wage elasticity of labor supply.

Firms. The firms demand labor to produce the consumption good. They face a working capital constraint that requires them to pay upfront a certain fraction of the wage bill, which they do 
with intra-period loans from international lenders. Hence, their problem is:

$$
\begin{aligned}
\max _{\left\{N, \ell^{d}\right\}} & \Pi^{F}=z F(N)-w N-r^{\ell} \ell \\
\text { s.t. } & \eta w N \leq \ell
\end{aligned}
$$

where $z$ is aggregate productivity, $N$ denotes labor demand, $F(N)$ is the production function, $\ell$ is the demand for working capital loans, $r^{\ell}$ is the interest rate charged for these loans, and $\eta$ is the fraction of the wage bill that must be paid upfront.

Equation (B.5) is the working capital constraint. This equation will always hold with equality because firms do not need loans for anything other than paying $\eta w N$; thus, any borrowing over and above $\eta w N$ would be sub-optimal. Taking this into account, we obtain the following firstorder condition:

$$
z F_{N}(N)=\left(1+\eta r^{\ell}\right) w,
$$

which equates the marginal product of labor to the marginal cost of hiring labor once the financing cost is factored in. Therefore, the optimality conditions from the firms' problem are represented by equation (B.5), evaluated with equality, and equation (B.6). In what follows we assume that

$$
F(N)=N^{\alpha} \quad \text { with } \alpha \in(0,1) \text {. }
$$

The intra-period loans taken by firms, similarly to government debt, may be indexed to the underlying state of the economy $(z)$. We assume that the firms' borrowing opportunities are such that:

$$
r^{\ell}= \begin{cases}r+\alpha^{r} E\left(d^{\prime}\right)+\phi^{f}(\bar{z}-z), & \text { if the gov't repays } \\ r_{D}, & \text { otherwise }\end{cases}
$$

where $r$ is the international risk-free rate, $E\left(d^{\prime}\right)$ denotes the one-period-ahead default probability, $\alpha^{r}$ captures the slope of the private borrowing rate with respect to default risk, $\phi^{f}$ controls the degree of indexation of firm loans, and $\bar{z}$ denotes the mean productivity level. If the government declares a default, then the firm's borrowing costs are just given by $r_{D}$.

Note that the interest rate faced by firms depends on the indexation of both private and public debt. Private indexation, $\phi^{f}$, enters directly. Public indexation enters indirectly: it affects the default probability, $E\left(d^{\prime}\right){ }^{31}$

Government finances. The (consolidated) government decides on debt, reserves and (potentially) default. The asset space is the same as in the main body of the paper. A bond issued in period $t$ promises an infinite stream of coupons, whose unconditional mean decreases at a constant rate $\delta$. In particular, a bond issued issued in period $t$ promises to pay $\kappa\left[1+\phi^{g}\left(z_{t+j}-\bar{z}\right)\right](1-\delta)^{j-1}$ units of the tradable good in period $t+j$, for all $j \geq 1$. This bonds trade at a price of $q$. Re-

\footnotetext{
${ }^{31}$ Note that the degree of indexation in the private sector's debt also has an impact on the government finances. For example, if the representative firm is borrowing 'all in dollars' (that would be $\phi^{f}=0$ ) then it has no hedging, so a bad productivity realization will increase what they need to pay - that amplifies the negative effect on labor demand and reinforces the drop in output. This, in turn, lowers tax revenues for the government and, other things equal, increases debt issuance needs (and future default risk).
} 
serves are modeled as one-period risk-free assets, trade at a price of $q_{a}$, and pay one unit of the consumption good in the next period. The government budget constraint under repayment is:

$$
\kappa\left[1+\phi^{g}(z-\bar{z})\right] b+a^{\prime} q_{a}=T+q\left(b^{\prime}, a^{\prime}, z\right)\left(b^{\prime}-(1-\delta) b\right)+a
$$

where $T$ are lump-sum taxes. The government budget constraint under default is:

$$
a^{\prime} q_{a}=T+a
$$

International lenders. Bonds are priced in a competitive market inhabited by a large number of identical lenders. These lenders are subject to risk-premia shocks, which makes them alternate (with certain probability) between been risk-neutral or risk-averse agents. The modelling of international lenders is identical to the one in the main body of the paper. For brevity, we omit any further details here.

Defaults. We keep the assumption that when the government defaults, it does so on all current and future debt obligations. ${ }^{32}$ Upon default, the government retains control of its reserves and access to savings but cannot borrow in the default period. A default entails a productivity loss $\lambda_{d}(z)$, which depends on the realization of productivity. We still abstract from financial exclusion as an additional source of default penalty (but adding this type of default penalty is straightforward). That is, the government can once again borrow from international markets in the period following a default.

\section{B.2 Recursive Problem}

We consider a Markov equilibrium, in which all policies depend on the payoff-relevant states $(b, a, z)$. The timing of events is identical to the one in the main body of the text. Let $d$ denote the current-period default decision. We assume that $d$ is equal to 1 if the government defaulted in the current period and is equal to 0 if it did not. Let $V$ denote the government's value function at the beginning of a period, that is, before the default decision is made. Let $V_{0}$ denote the value function of a sovereign not in default. Let $V_{1}$ denote the value function of a sovereign in default. For any bond price function $q$, the function $V$ satisfies the following functional equation:

$$
V(b, a, z)=\max _{d \in\{0,1\}}\left\{d V_{1}(a, z)+(1-d) V_{0}(b, a, z)\right\}
$$

where

$$
V_{0}(b, a, z)=\max _{b^{\prime}, a^{\prime}, c, n, \ell}\left\{\frac{\left(c-\chi \frac{n^{\nu}}{\nu}\right)^{1-\gamma}}{1-\gamma}+\beta \mathbb{E}_{z^{\prime} \mid z} V\left(b^{\prime}, a^{\prime}, z^{\prime}\right)\right\}
$$

\footnotetext{
${ }^{32}$ This is a standard assumption in the literature. See footnote 12 for a further discussion.
} 
subject to

$$
\begin{aligned}
& c+\kappa\left[1+\phi^{g}(z-\bar{z})\right] b+a^{\prime} q_{a}+\ell r^{\ell}=Y^{*}+q\left(b^{\prime}, a^{\prime}, z\right)\left(b^{\prime}-(1-\delta) b\right)+a \\
& \ell=\eta w^{*} n^{*} \\
& n^{*}=\left(\frac{\alpha z}{\chi\left(1+\eta r^{\ell}\right)}\right)^{\frac{1}{\nu-\alpha}} \\
& w^{*}=\chi\left(n^{*}\right)^{\nu-1} \\
& Y^{*}=z\left(n^{*}\right)^{\alpha} \\
& \text { with } r^{\ell} \text { given by (B.7) }
\end{aligned}
$$

The value of default is:

$$
V_{1}(a, z)=\max _{a^{\prime}, c, n, \ell}\left\{\frac{\left(c-\chi \frac{n^{\nu}}{\nu}\right)^{1-\gamma}}{1-\gamma}+\beta \mathbb{E}_{z^{\prime} \mid z} V\left(0, a^{\prime}, z^{\prime}\right)\right\}
$$

subject to

$$
\begin{aligned}
c+a^{\prime} q_{a}+\ell r_{D} & =Y^{*}+a \\
\ell & =\eta w^{*} n^{*} \\
n^{*} & =\left(\frac{\alpha z_{D}}{\chi\left(1+\eta r_{D}\right)}\right)^{\frac{1}{\nu-\alpha}} \\
w^{*} & =\chi\left(n^{*}\right)^{\nu-1} \\
Y^{*} & =z_{D}\left(n^{*}\right)^{\alpha} \\
z_{D} & =z-\lambda_{d}(z)
\end{aligned}
$$

For brevity we omit the (usual) definition of the Markov perfect equilibrium of this problem.

\section{B.3 Calibration}

The recursive government problem is solved using value function iteration, following the same procedure as in the main body of the paper. We now refer to the model with non-state contingent public and private debt (i.e. with $\phi^{g}=\phi^{f}=0$ ) as the benchmark model and calibrate it to an annual frequency.

We split the parameters of the model into two groups. The first group of parameters (those in the top part of Table B.1) take values that can be set either directly from the data, using typical values from the literature, or are unchanged from the calibration in the main body of the paper. The second group of parameter values (those in the bottom part of Table B.1) are set by simultaneously matching key moments from the data.

The logarithm of domestic productivity follow an AR(1) process,

$$
\log \left(z_{t}\right)=\left(1-\rho_{z}\right) \mu_{z}+\rho_{z} \log \left(z_{t-1}\right)+\varepsilon_{t}^{z},
$$

with $\left|\rho_{z}\right|<1$ and $\varepsilon^{z} \stackrel{i i d}{\sim} N\left(0, \sigma_{\varepsilon^{z}}^{2}\right)$. 
Table B.1: Parameter values for the benchmark model with production

\begin{tabular}{llc}
\hline \hline Parameter & Description & Value \\
\hline$r$ & Risk-free rate & 0.04 \\
$\beta$ & Domestic discount factor & 0.90 \\
$\pi_{L H}$ & Prob. of transitioning to high risk premium & 0.15 \\
$\pi_{H L}$ & Prob. of transitioning to low risk premium & 0.8 \\
$\sigma_{\varepsilon^{z}}$ & Std. dev. of innovation to $\log (z)$ & 0.03 \\
$\rho_{z}$ & Autocorrelation of $\log (z)$ & 0.90 \\
$\mu_{z}$ & Mean of log $(z)$ & $-\frac{1}{2} \sigma_{\varepsilon^{z}}^{2}$ \\
$\delta$ & Coupon decaying rate & 0.2845 \\
$\kappa$ & Avg. coupon size & $+\delta) e^{-r}$ \\
$\alpha$ & Labor share & 0.75 \\
$\eta$ & Working capital constraint & 0.52 \\
$1 /(\nu-1)$ & Frisch elasticity & 0.67 \\
$\chi$ & Weight of labor disutility & 1.0 \\
& Parameters set by simulation & \\
\hline & & \\
$\gamma$ & Coefficient of relative risk aversion & 3.0 \\
$\lambda_{0}$ & Default cost parameter & 0.285 \\
$\lambda_{1}$ & Default cost parameter & 2.25 \\
$\omega_{H}$ & Pricing kernel parameter & 27 \\
$r_{D}$ & Corporate borrowing cost in default & 0.08 \\
$\alpha^{r}$ & Sensitivity of $r^{\ell}$ to sovereign default risk & 0.07 \\
\hline \hline
\end{tabular}

We assume the following functional form for the productivity cost of default,

$$
\lambda_{d}(z)=\max \left\{0, \lambda_{0}+\lambda_{1} z\right\} .
$$

The parameter values that govern the productivity endowment process are set to standard values in the literature, $\rho_{z}=0.9$ and $\sigma_{\varepsilon^{z}}=0.03$. We set $\mu_{z}=-\frac{1}{2} \sigma_{\varepsilon^{z}}^{2}$ so that mean productivity is normalized to one (i.e. $\bar{z}=1$ ). The values of the risk-free interest rate and the domestic discount factor are set to $r=0.04$ and $\beta=0.9$, which are standard in quantitative sovereign default studies. We set $\delta=0.2845$, which is the value used in the main text of the paper.

The risk-premium process is again modeled as a two-point Markov chain. The low value (implying risk-netruality) is still $\omega_{L}=0$, and the high value is calibrated following the strategy described below. The transition matrix for this shock is the same we used in the main text: $\pi_{L H}=0.15$ and $\pi_{H L}=0.8$.

The parameters that relate to the firm problem are set following Hur et al. (2022): $\eta=0.52$ and $\alpha=0.75$. We normalize the parameter $\chi$, which is the weight of labor disutility (and therefore governs the level of the labor supply), to 1 and set the Frisch wage elasticity of labor supply, 1/( $\nu-1)$, to 0.67 (the value used in Hur et al., 2022 and a value in the middle range of the empirical estimates). Finally, note that this extended model with production can be reparametrized so that it collapses to an endowment economy (essentially identical to the one in 
the main body of the paper). ${ }^{33}$

Targeted moments. The calibration strategy described so far leaves six parameters to assign values to: the default cost parameters $\left(\lambda_{0}\right.$ and $\left.\lambda_{1}\right)$, the sensitivity of the corporate borrowing rate (under repay) to sovereign default risk $\left(\alpha^{r}\right)$, the corporate borrowing rate under default $\left(r_{D}\right)$, the risk premium parameter $\left(\omega_{H}\right)$, and the risk aversion parameter $(\gamma)$. We target the following six moments: (i) a mean debt-to-GDP ratio of 19\%, (ii) a mean sovereign spread of 3.2\%, (iii) a correlation between the corporate borrowing rate (under repayment) and the sovereign spread of 0.5 , (iv) an average increase in the corporate borrowing rate of $4 \%$ during defaults, (v) an increase of 200 basis points in the spread during high-risk premium periods, and (vi) a volatility of consumption relative to output equal to 1 .

The empirical counterparts of (i), (ii) and (vi) are the medians for the countries in our panel (see Appendix A). The counterparts for (iii) and (iv) are computed using data for the corporate borrowing rate for all the countries listed in Table A.2 for which this data was available. ${ }^{34}$ The empirical counterpart for $(\mathrm{v})$ is the same ones used in the main text of the paper.

\section{B.4 Results}

Model fit. The first two columns of Table B.2 show that the simulations of the benchmark model match well the targeted moments. The model also does a good job in mimicking other non-targeted moments. In particular, the model is able to capture the countercyclicality of sovereign spreads and the procyclicality of consumption. This calibration strategy produces a mean reserves-to-GDP ratio (which was not targeted) that is roughly one-fourth of the one in the data, and one-half of the ratio observed in the baseline model presented in the main text. ${ }^{35}$

\footnotetext{
${ }^{33}$ In particular, if we set the weight on labor disutility to one $(\chi=1)$ households will inelastically supply their endowment of hours (normalized to one). Then, if we remove the working capital constraint by setting $\eta=0$ then the movements in the sovereign spread do not matter for output. So, this re-parametrization collapses output to just stochastic productivity: this is exactly what we have in the stochastic endowment economy in the main text. Next, one needs to recalibrate the pricing kernel parameter and the coefficient of risk aversion back to their original values. Finally, a qualification about the cost-of-default parameters: the benchmark economy has utility costs of default while the production model has output costs of default. Assuming logarithmic utility over consumption and that output losses from default are proportional to consumption in default, then the losses from default are identical for the output and utility cost specifications.

${ }^{34}$ The time series used for the corporate borrowing rate is taken from the IMF-IFS: "Interest Rates, Lending Rate" (code: FILR_PA).

${ }^{35}$ Note that, of the four economies whose simulations we report in this table, only the benchmark (i.e. $\phi^{g}=$ $\left.\phi^{f}=0\right)$ was calibrated to the targeted moments. This is the same approach taken in the main text.
} 
Table B.2: Key statistics - model (w/ production) and data

\begin{tabular}{|c|c|c|c|c|c|}
\hline & \multirow[t]{3}{*}{ Data } & \multicolumn{4}{|c|}{ Model } \\
\hline & & \multicolumn{2}{|c|}{$\phi^{f}=0$} & \multicolumn{2}{|c|}{$\phi^{f}=1$} \\
\hline & & $\phi^{g}=0$ & $\phi^{g}=1$ & $\phi^{g}=0$ & $\phi^{g}=1$ \\
\hline \multicolumn{6}{|l|}{ Targeted } \\
\hline Mean debt $(b / Y)$ & 19 & 19.0 & 21.5 & 15.4 & 18.0 \\
\hline Mean $r_{s}($ in $\%)$ & 3.2 & 3.2 & 2.7 & 3.3 & 2.7 \\
\hline$\rho\left(r^{\ell}, r_{s}\right)$ & 0.5 & 0.8 & 0.8 & 0.8 & 0.9 \\
\hline$\Delta r^{\ell}$ in defaults & 4.0 & 3.7 & 3.7 & 7.5 & 7.6 \\
\hline$\Delta r_{s} \mathrm{w} /$ risk-prem. shock & 2.0 & 2.1 & 3.0 & 2.2 & 3.2 \\
\hline$\sigma(c) / \sigma(Y)$ & 1.0 & 1.1 & 1.1 & 1.2 & 1.2 \\
\hline \multicolumn{6}{|l|}{ Non-Targeted } \\
\hline$\sigma\left(r_{s}\right)($ in $\%)$ & 3.3 & 2.9 & 3.9 & 3.3 & 4.2 \\
\hline$\rho\left(r_{s}, Y\right)$ & -0.3 & -0.7 & -0.8 & -0.7 & -0.8 \\
\hline$\rho(c, Y)$ & 0.95 & 0.99 & 0.99 & 0.99 & 0.99 \\
\hline Mean Reserves $(a / Y)$ & 13 & 2.8 & 3.8 & 5.9 & 7.3 \\
\hline
\end{tabular}

Note: Moments in the model are computed for the average of pre-default simulation samples. We simulate the model for 1,000 samples of 300 periods each. We then take the last 35 observations of each sample in which the last default was observed at least 25 periods before the beginning of the sample.

Main result. The last three columns of Table B.2 show how the simulation moments change when we introduce different forms of indexed debt. ${ }^{36}$ We can see that most of the effects found with the baseline model in the main text are still features of this new framework: having access to indexed sovereign bonds induces the government to increase its debt, most of this higher indebtedness goes to increasing the reserve ratio, and this change in the portfolio has non-trivial implications for the spread. ${ }^{37}$

The main take-away is that our headline result, namely that financing reserves with statecontingent sovereign debt reduces spreads, is robust to the modifications introduced in this appendix (i.e, a production economy with the possibility of indexed private debt). In particular, Figure B.1 shows that the main testable implication of our theory is robust to different degrees of firm debt indexation. Namely, for a given level of debt, financing reserve accumulation with contingent government debt (in particular, using an instrument indexed to the performance of domestic income) allows the country to pay lower spreads than it would otherwise (i.e., had it used non-state contingent debt instead), and this holds irrespective of whether the private sector is borrowing with or without indexed debt.

\footnotetext{
${ }^{36}$ In all cases, keeping with the exercise done in the main text, we introduce state contingency in the asset payments by setting $\phi^{x}=1$, with $x=\{f, g\}$.

${ }^{37}$ Note that in this case, we observe the spread being lower with indexed government debt even on average. Even though the change in the portfolio is qualitatively the same as in the main text, the quantitative impact is not as large, which explains that consumption volatility is mostly unaffected.
} 

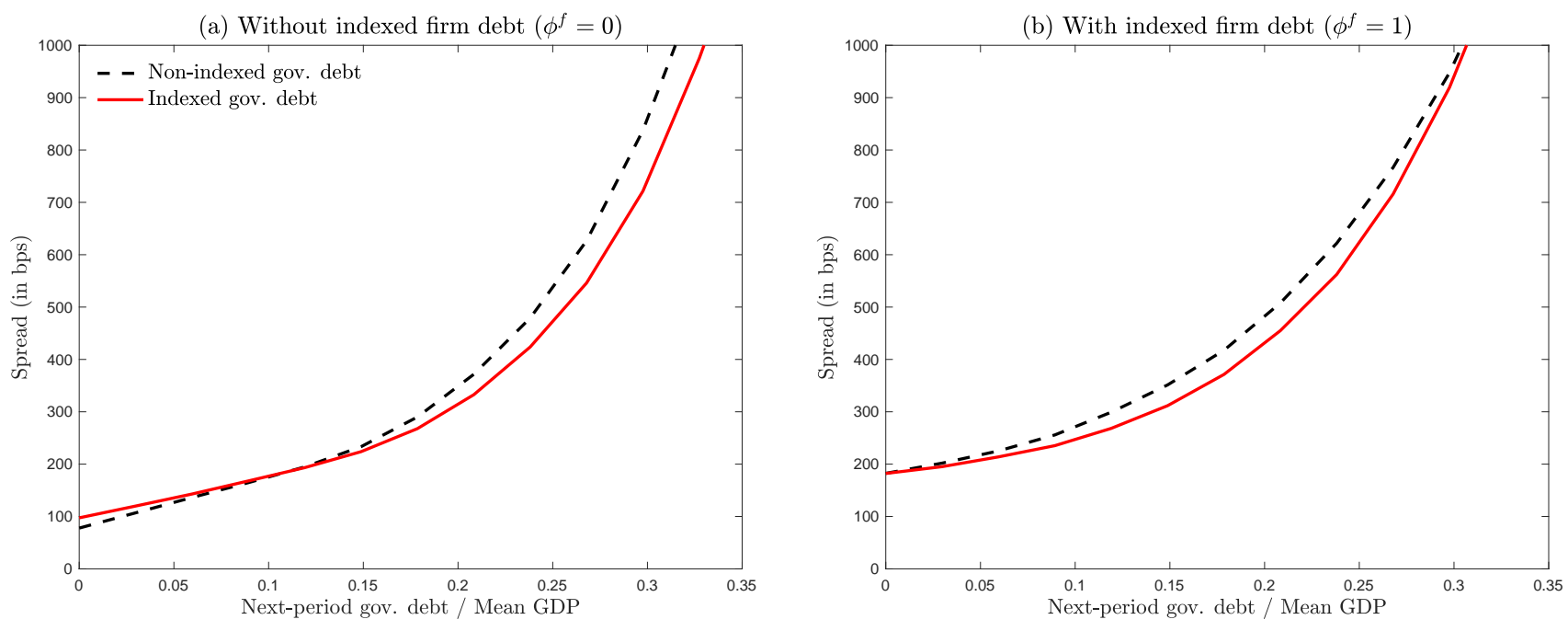

Figure B.1: Spread-debt menus and debt indexation in a production economy

Note: The figure is computed for the mean income and the mean reserve levels in the simulations of the benchmark model $\left(\phi^{g}=\phi^{f}=0\right)$, and assuming no risk-premium shock in the current period $\left(\omega_{t}=0\right)$. 


\section{Online appendix (not for publication)}

Table C.1: Regression results. Robustness Checks

\begin{tabular}{|c|c|c|c|c|c|c|c|c|}
\hline & \multicolumn{8}{|c|}{ Dependent variable: $\log ($ spread) } \\
\hline & $(1)$ & $(2)$ & $(3)$ & $(4)$ & $(5)$ & $(6)$ & $(7)$ & $(8)$ \\
\hline Risk Aversion & $\begin{array}{c}0.67^{* * *} \\
(0.05)\end{array}$ & $\begin{array}{c}0.70^{* * *} \\
(0.05)\end{array}$ & $\begin{array}{l}0.94^{* * *} \\
(0.05)\end{array}$ & $\begin{array}{l}0.94^{* * *} \\
(0.05)\end{array}$ & $\begin{array}{l}0.94^{* * *} \\
(0.05)\end{array}$ & $\begin{array}{c}0.71^{* * *} \\
(0.05)\end{array}$ & $\begin{array}{c}0.71^{* * *} \\
(0.05)\end{array}$ & $\begin{array}{c}0.71^{* * *} \\
(0.05)\end{array}$ \\
\hline Rating & $\begin{array}{c}-2.12^{* * *} \\
(0.41)\end{array}$ & $\begin{array}{c}-1.98^{* * *} \\
(0.62)\end{array}$ & $\begin{array}{c}-2.06^{* * *} \\
(0.75)\end{array}$ & $\begin{array}{c}-2.04^{* * *} \\
(0.76)\end{array}$ & $\begin{array}{c}-2.03^{* * *} \\
(0.75)\end{array}$ & $\begin{array}{c}-1.83^{* * *} \\
(0.61)\end{array}$ & $\begin{array}{c}-1.81^{* * *} \\
(0.62)\end{array}$ & $\begin{array}{c}-1.81^{* * *} \\
(0.63)\end{array}$ \\
\hline World Rate & $\begin{array}{c}-0.30^{* *} \\
(0.14)\end{array}$ & $\begin{array}{l}-0.19 \\
(0.14)\end{array}$ & $\begin{array}{l}0.15^{* *} \\
(0.07)\end{array}$ & $\begin{array}{l}0.15^{* *} \\
(0.07)\end{array}$ & $\begin{array}{l}0.15^{* *} \\
(0.07)\end{array}$ & $\begin{array}{l}-0.20 \\
(0.14)\end{array}$ & $\begin{array}{l}-0.19 \\
(0.14)\end{array}$ & $\begin{array}{l}-0.19 \\
(0.14)\end{array}$ \\
\hline Reserve Ratio & $\begin{array}{c}-2.41^{* *} \\
(1.04)\end{array}$ & $\begin{array}{c}-2.37^{* * *} \\
(0.62)\end{array}$ & $\begin{array}{l}-0.33 \\
(0.93)\end{array}$ & $\begin{array}{c}-2.80^{* *} \\
(1.15)\end{array}$ & $\begin{array}{c}-2.47^{* *} \\
(1.24)\end{array}$ & $\begin{array}{l}-0.97 \\
(0.68)\end{array}$ & $\begin{array}{c}-3.32^{* * *} \\
(0.62)\end{array}$ & $\begin{array}{c}-3.53^{* * *} \\
(1.08)\end{array}$ \\
\hline Sovereign Debt & $\begin{array}{c}0.06 \\
(0.26)\end{array}$ & $\begin{array}{c}0.92 \\
(0.64)\end{array}$ & $\begin{array}{c}0.36 \\
(0.69)\end{array}$ & $\begin{array}{c}0.15 \\
(0.65)\end{array}$ & $\begin{array}{c}0.17 \\
(0.63)\end{array}$ & $\begin{array}{l}1.08 \\
(0.72)\end{array}$ & $\begin{array}{c}0.91 \\
(0.74)\end{array}$ & $\begin{array}{c}0.89 \\
(0.66)\end{array}$ \\
\hline Private Debt & $\begin{array}{l}1.25 \\
(0.87)\end{array}$ & $\begin{array}{l}2.17^{* *} \\
(1.04)\end{array}$ & $\begin{array}{l}1.36^{*} \\
(0.70)\end{array}$ & $\begin{array}{l}1.32^{*} \\
(0.68)\end{array}$ & $\begin{array}{l}1.32^{* *} \\
(0.67)\end{array}$ & $\begin{array}{l}2.21^{* *} \\
(1.03)\end{array}$ & $\begin{array}{l}2.14^{* *} \\
(1.03)\end{array}$ & $\begin{array}{l}2.13^{* *} \\
(1.02)\end{array}$ \\
\hline $\begin{array}{l}\text { Remunerated } \\
\text { Domestic Liabilites }\end{array}$ & & & $\begin{array}{l}-2.50^{*} \\
(1.28)\end{array}$ & & $\begin{array}{l}-0.36 \\
(1.23)\end{array}$ & $\begin{array}{c}-2.38^{* *} \\
(1.13)\end{array}$ & & $\begin{array}{c}0.22 \\
(1.29)\end{array}$ \\
\hline $\begin{array}{l}\text { Unsterilized } \\
\text { Purchases }\end{array}$ & & & $\begin{array}{l}-1.95 \\
(1.52)\end{array}$ & $\begin{array}{c}0.32 \\
(1.02)\end{array}$ & & $\begin{array}{l}-2.38^{*} \\
(1.28)\end{array}$ & $\begin{array}{l}-0.21 \\
(1.10)\end{array}$ & \\
\hline $\begin{array}{l}\text { Others } \\
\text { Balance Sheet }\end{array}$ & & & $\begin{array}{l}-0.47 \\
(1.10)\end{array}$ & $\begin{array}{c}2.26^{* * *} \\
(0.52)\end{array}$ & $\begin{array}{c}1.90 \\
(1.20)\end{array}$ & $\begin{array}{l}-0.76 \\
(0.86)\end{array}$ & $\begin{array}{c}1.87^{* * *} \\
(0.55)\end{array}$ & $\begin{array}{c}2.09 \\
(1.40)\end{array}$ \\
\hline External Liabilities & & & & $\begin{array}{l}3.33^{* *} \\
(1.52)\end{array}$ & $\begin{array}{c}2.94 \\
(2.07)\end{array}$ & & $\begin{array}{l}3.24^{* *} \\
(1.42)\end{array}$ & $\begin{array}{c}3.48^{*} \\
(1.86)\end{array}$ \\
\hline $\begin{array}{l}\text { Current } \\
\text { Account }\end{array}$ & $\begin{array}{l}-0.51 \\
(0.39)\end{array}$ & $\begin{array}{l}-0.02 \\
(0.33)\end{array}$ & $\begin{array}{c}0.06 \\
(0.26)\end{array}$ & $\begin{array}{c}0.04 \\
(0.27)\end{array}$ & $\begin{array}{c}0.04 \\
(0.26)\end{array}$ & $\begin{array}{c}0.07 \\
(0.33)\end{array}$ & $\begin{array}{c}0.06 \\
(0.34)\end{array}$ & $\begin{array}{c}0.06 \\
(0.33)\end{array}$ \\
\hline $\begin{array}{l}\text { Fiscal } \\
\text { Deficit }\end{array}$ & $\begin{array}{c}0.53 \\
(0.50)\end{array}$ & $\begin{array}{c}0.15 \\
(0.50)\end{array}$ & $\begin{array}{l}-0.05 \\
(0.70)\end{array}$ & $\begin{array}{l}-0.02 \\
(0.68)\end{array}$ & $\begin{array}{l}-0.03 \\
(0.68)\end{array}$ & $\begin{array}{l}-0.07 \\
(0.60)\end{array}$ & $\begin{array}{l}-0.08 \\
(0.57)\end{array}$ & $\begin{array}{l}-0.08 \\
(0.57)\end{array}$ \\
\hline Constant & $\begin{array}{c}7.98^{* * *} \\
(1.07)\end{array}$ & & & & & & & \\
\hline $\begin{array}{l}\text { Fixed effects? } \\
\text { Year dummies? } \\
\text { Observations } \\
\text { Adjusted } \mathrm{R}^{2}\end{array}$ & $\begin{array}{c}\text { No } \\
\text { No } \\
1,975 \\
0.66\end{array}$ & $\begin{array}{c}\text { Yes } \\
\text { No } \\
1,975 \\
0.59\end{array}$ & $\begin{array}{c}\text { Yes } \\
\text { No } \\
1,975 \\
0.65\end{array}$ & $\begin{array}{c}\text { Yes } \\
\text { No } \\
1,975 \\
0.65\end{array}$ & $\begin{array}{c}\text { Yes } \\
\text { No } \\
1,975 \\
0.65\end{array}$ & $\begin{array}{c}\text { Yes } \\
\text { Yes } \\
1,975 \\
0.60\end{array}$ & $\begin{array}{c}\text { Yes } \\
\text { Yes } \\
1,975 \\
0.60\end{array}$ & $\begin{array}{c}\text { Yes } \\
\text { Yes } \\
1,975 \\
0.60\end{array}$ \\
\hline
\end{tabular}

Note: Robust standard errors in parentheses. Risk Aversion, Rating and World rate are expressed in $\operatorname{logs}$, the remaining variables are ratios of GDP. ${ }^{*} \mathrm{p}<0.1 ;{ }^{* *} \mathrm{p}<0.05 ;{ }^{* * *} \mathrm{p}<0.01$ 
Table C.2: Regression Results. Split Sample by Debt

\begin{tabular}{|c|c|c|c|c|c|c|}
\hline & \multicolumn{6}{|c|}{ Dependent variable: } \\
\hline & \multicolumn{6}{|c|}{$\log ($ spread $)$} \\
\hline & \multicolumn{3}{|c|}{ High Debt } & \multicolumn{3}{|c|}{ Low Debt } \\
\hline & $(1)$ & $(2)$ & $(3)$ & $(4)$ & $(5)$ & $(6)$ \\
\hline Risk Aversion & $\begin{array}{c}0.85^{* * *} \\
(0.12)\end{array}$ & $\begin{array}{c}0.85^{* * *} \\
(0.12)\end{array}$ & $\begin{array}{c}0.85^{* * *} \\
(0.12)\end{array}$ & $\begin{array}{c}1.07^{* * *} \\
(0.06)\end{array}$ & $\begin{array}{c}1.06^{* * *} \\
(0.06)\end{array}$ & $\begin{array}{c}1.07^{* * *} \\
(0.06)\end{array}$ \\
\hline Rating & $\begin{array}{c}-0.28^{* * *} \\
(0.07)\end{array}$ & $\begin{array}{c}-0.27^{* * *} \\
(0.07)\end{array}$ & $\begin{array}{c}-0.28^{* * *} \\
(0.07)\end{array}$ & $\begin{array}{c}-2.61^{* * *} \\
(0.38)\end{array}$ & $\begin{array}{c}-2.80^{* * *} \\
(0.38)\end{array}$ & $\begin{array}{c}-2.82^{* * *} \\
(0.38)\end{array}$ \\
\hline World Rate & $\begin{array}{l}0.22^{* *} \\
(0.09)\end{array}$ & $\begin{array}{l}0.22^{* *} \\
(0.09)\end{array}$ & $\begin{array}{l}0.22^{* *} \\
(0.09)\end{array}$ & $\begin{array}{c}0.26^{* * *} \\
(0.07)\end{array}$ & $\begin{array}{c}0.26^{* * *} \\
(0.07)\end{array}$ & $\begin{array}{c}0.26^{* * *} \\
(0.07)\end{array}$ \\
\hline Reserve Ratio & $\begin{array}{l}-0.33 \\
(1.18)\end{array}$ & $\begin{array}{c}-3.47^{* * *} \\
(0.89)\end{array}$ & $\begin{array}{l}-0.24 \\
(1.01)\end{array}$ & $\begin{array}{c}0.20 \\
(1.37)\end{array}$ & $\begin{array}{l}-1.26 \\
(0.77)\end{array}$ & $\begin{array}{l}-1.16 \\
(1.75)\end{array}$ \\
\hline Sovereign Debt & $\begin{array}{l}-0.06 \\
(0.71)\end{array}$ & $\begin{array}{l}-0.15 \\
(0.68)\end{array}$ & $\begin{array}{l}-0.06 \\
(0.71)\end{array}$ & $\begin{array}{c}0.07 \\
(1.26)\end{array}$ & $\begin{array}{c}0.13 \\
(1.32)\end{array}$ & $\begin{array}{c}0.21 \\
(1.20)\end{array}$ \\
\hline Private Debt & $\begin{array}{l}-0.35 \\
(0.37)\end{array}$ & $\begin{array}{l}-0.27 \\
(0.35)\end{array}$ & $\begin{array}{l}-0.34 \\
(0.39)\end{array}$ & $\begin{array}{c}0.59 \\
(0.49)\end{array}$ & $\begin{array}{c}0.59 \\
(0.48)\end{array}$ & $\begin{array}{c}0.51 \\
(0.46)\end{array}$ \\
\hline $\begin{array}{l}\text { Remunerated } \\
\text { Domestic Liabilites }\end{array}$ & $\begin{array}{l}-3.46^{*} \\
(1.82)\end{array}$ & & $\begin{array}{c}-3.55^{* *} \\
(1.59)\end{array}$ & $\begin{array}{l}-1.90 \\
(1.62)\end{array}$ & & $\begin{array}{l}-0.53 \\
(1.77)\end{array}$ \\
\hline $\begin{array}{l}\text { Unsterilized } \\
\text { Purchases }\end{array}$ & $\begin{array}{c}0.09 \\
(1.02)\end{array}$ & $\begin{array}{l}3.19^{* *} \\
(1.45)\end{array}$ & & $\begin{array}{l}-1.95 \\
(1.52)\end{array}$ & $\begin{array}{l}-0.47 \\
(1.84)\end{array}$ & \\
\hline $\begin{array}{l}\text { Others } \\
\text { Balance Sheet }\end{array}$ & $\begin{array}{l}-1.48 \\
(1.02)\end{array}$ & $\begin{array}{c}1.63 \\
(1.08)\end{array}$ & $\begin{array}{c}-1.57^{* *} \\
(0.77)\end{array}$ & $\begin{array}{l}-0.92 \\
(1.57)\end{array}$ & $\begin{array}{c}0.64 \\
(0.91)\end{array}$ & $\begin{array}{c}0.35 \\
(2.06)\end{array}$ \\
\hline External Liabilities & & $\begin{array}{l}3.87^{* *} \\
(1.97)\end{array}$ & $\begin{array}{l}-0.09 \\
(1.18)\end{array}$ & & $\begin{array}{l}-0.65 \\
(1.89)\end{array}$ & $\begin{array}{l}-0.76 \\
(1.68)\end{array}$ \\
\hline Observations & 1,188 & 1,188 & 1,188 & 1,734 & 1,734 & 1,734 \\
\hline Adjusted $\mathrm{R}^{2}$ & 0.70 & 0.70 & 0.70 & 0.72 & 0.72 & 0.72 \\
\hline
\end{tabular}

Note: Robust standard errors in parentheses. Risk Aversion, Rating and World rate are expressed in logs, the remaining variables are ratios of GDP. All regressions include year and country fixed effects. ${ }^{*} p<0.1 ;^{* *} p<0.05 ;^{* * *} p<0.01$. 
Table C.3: Regression Results. Split Sample by Spreads

\begin{tabular}{|c|c|c|c|c|c|c|}
\hline & \multicolumn{6}{|c|}{ Dependent variable: } \\
\hline & \multicolumn{6}{|c|}{$\log$ (spread) } \\
\hline & \multicolumn{3}{|c|}{ High Spread } & \multicolumn{3}{|c|}{ Low Spread } \\
\hline & (1) & (2) & (3) & (4) & (5) & (6) \\
\hline Risk Aversion & $\begin{array}{c}0.98^{* * *} \\
(0.06)\end{array}$ & $\begin{array}{c}1.00^{* * *} \\
(0.06)\end{array}$ & $\begin{array}{c}0.99^{* * *} \\
(0.06)\end{array}$ & $\begin{array}{c}0.90^{* * *} \\
(0.05)\end{array}$ & $\begin{array}{c}0.90^{* * *} \\
(0.05)\end{array}$ & $\begin{array}{c}0.91^{* * *} \\
(0.05)\end{array}$ \\
\hline Rating & $\begin{array}{c}-0.32^{* *} \\
(0.15)\end{array}$ & $\begin{array}{c}-0.31^{* *} \\
(0.13)\end{array}$ & $\begin{array}{c}-0.31^{\text {** }} \\
(0.13)\end{array}$ & $\begin{array}{c}-0.41^{* * *} \\
(0.09)\end{array}$ & $\begin{array}{c}-0.42^{* * *} \\
(0.09)\end{array}$ & $\begin{array}{c}-0.41^{* * *} \\
(0.10)\end{array}$ \\
\hline World Rate & $\begin{array}{c}0.20^{* * *} \\
(0.05)\end{array}$ & $\begin{array}{c}0.21^{* * *} \\
(0.05)\end{array}$ & $\begin{array}{c}0.21^{* * *} \\
(0.05)\end{array}$ & $\begin{array}{l}0.20^{* *} \\
(0.08)\end{array}$ & $\begin{array}{c}0.20^{* * *} \\
(0.08)\end{array}$ & $\begin{array}{l}0.20^{* *} \\
(0.08)\end{array}$ \\
\hline Reserve Ratio & $\begin{array}{l}0.67 \\
(1.57)\end{array}$ & $\begin{array}{c}-2.92^{* * *} \\
(0.51)\end{array}$ & $\begin{array}{l}-0.98 \\
(0.69)\end{array}$ & $\begin{array}{l}-0.06 \\
(1.21)\end{array}$ & $\begin{array}{l}-1.35 \\
(1.47)\end{array}$ & $\begin{array}{c}-5.52^{* * *} \\
(1.42)\end{array}$ \\
\hline Sovereign Debt & $\begin{array}{c}0.01 \\
(0.70)\end{array}$ & $\begin{array}{l}-0.31 \\
(0.63)\end{array}$ & $\begin{array}{l}-0.40 \\
(0.65)\end{array}$ & $\begin{array}{l}1.50^{* *} \\
(0.61)\end{array}$ & $\begin{array}{c}1.69^{* * *} \\
(0.61)\end{array}$ & $\begin{array}{l}1.40^{*} \\
(0.81)\end{array}$ \\
\hline Private Debt & $\begin{array}{c}0.93^{*} \\
(0.56)\end{array}$ & $\begin{array}{c}0.89^{*} \\
(0.48)\end{array}$ & $\begin{array}{l}1.11^{* *} \\
(0.46)\end{array}$ & $\begin{array}{c}0.90 \\
(0.64)\end{array}$ & $\begin{array}{c}0.96 \\
(0.68)\end{array}$ & $\begin{array}{c}0.71 \\
(0.67)\end{array}$ \\
\hline $\begin{array}{l}\text { Remunerated } \\
\text { Domestic Liabilites }\end{array}$ & $\begin{array}{r}-3.76^{* *} \\
(1.88)\end{array}$ & & $\begin{array}{c}-1.77^{* *} \\
(0.84)\end{array}$ & $\begin{array}{l}-2.28 \\
(2.67)\end{array}$ & & $\begin{array}{l}3.14 \\
(2.23)\end{array}$ \\
\hline $\begin{array}{l}\text { Unsterilized } \\
\text { Purchases }\end{array}$ & $\begin{array}{l}-1.26 \\
(1.76)\end{array}$ & $\begin{array}{c}2.59^{* * *} \\
(0.69)\end{array}$ & & $\begin{array}{c}-5.89^{* * *} \\
(0.76)\end{array}$ & $\begin{array}{c}-4.76^{* * *} \\
(1.41)\end{array}$ & \\
\hline $\begin{array}{l}\text { Others } \\
\text { Balance Sheet }\end{array}$ & $\begin{array}{c}-3.13^{* *} \\
(1.45)\end{array}$ & $\begin{array}{l}1.11^{* *} \\
(0.44)\end{array}$ & $\begin{array}{l}-0.90^{*} \\
(0.50)\end{array}$ & $\begin{array}{l}-0.07 \\
(1.89)\end{array}$ & $\begin{array}{c}1.00 \\
(1.38)\end{array}$ & $\begin{array}{c}5.41^{* * *} \\
(1.19)\end{array}$ \\
\hline External Liabilities & & $\begin{array}{c}7.00^{* * *} \\
(1.08)\end{array}$ & $\begin{array}{c}5.02^{* * *} \\
(1.06)\end{array}$ & & $\begin{array}{c}0.05 \\
(2.50)\end{array}$ & $\begin{array}{l}5.26^{* *} \\
(2.33)\end{array}$ \\
\hline Obs & 2,517 & 2,517 & 2,517 & 1,980 & 1,980 & 1,980 \\
\hline Adjusted $\mathrm{R}^{2}$ & 0.65 & 0.68 & 0.68 & 0.68 & 0.68 & 0.66 \\
\hline
\end{tabular}

Note: Robust standard errors in parentheses. Risk Aversion, Rating and World rate are expressed in logs, the remaining variables are ratios of GDP. All regressions include year and country fixed effects. ${ }^{*} \mathrm{p}<0.1 ;{ }^{* *} \mathrm{p}<0.05 ;{ }^{* * *} \mathrm{p}<0.01$. 
Table C.4: Regression results. Split Sample by Rate of Devaluation

\begin{tabular}{|c|c|c|c|c|c|c|}
\hline & \multicolumn{6}{|c|}{ Dependent variable: } \\
\hline & \multicolumn{5}{|c|}{$\log ($ spread $)$} & \multirow[b]{3}{*}{ (6) } \\
\hline & \multicolumn{3}{|c|}{ High Rate } & \multicolumn{2}{|c|}{ Low Rate } & \\
\hline & (1) & (2) & (3) & (4) & (5) & \\
\hline Risk Aversion & $\begin{array}{l}0.97^{* * *} \\
(0.04)\end{array}$ & $\begin{array}{l}0.98^{* * *} \\
(0.04)\end{array}$ & $\begin{array}{l}0.98^{* * *} \\
(0.04)\end{array}$ & $\begin{array}{l}0.92^{* * *} \\
(0.07)\end{array}$ & $\begin{array}{l}0.92^{* * *} \\
(0.06)\end{array}$ & $\begin{array}{l}0.92^{* * *} \\
(0.06)\end{array}$ \\
\hline Rating & $\begin{array}{c}-0.35^{* *} \\
(0.14)\end{array}$ & $\begin{array}{c}-0.35^{* * *} \\
(0.13)\end{array}$ & $\begin{array}{l}-0.34^{* * *} \\
(0.13)\end{array}$ & $\begin{array}{r}-0.18^{*} \\
(0.11)\end{array}$ & $\begin{array}{r}-0.18^{*} \\
(0.11)\end{array}$ & $\begin{array}{l}-0.18 \\
(0.11)\end{array}$ \\
\hline World Rate & $\begin{array}{l}0.17^{* * *} \\
(0.06)\end{array}$ & $\begin{array}{l}0.17^{* * *} \\
(0.06)\end{array}$ & $\begin{array}{l}0.17^{* * *} \\
(0.06)\end{array}$ & $\begin{array}{l}0.22^{* * *} \\
(0.05)\end{array}$ & $\begin{array}{l}0.22^{* * *} \\
(0.05)\end{array}$ & $\begin{array}{l}0.22^{* * *} \\
(0.05)\end{array}$ \\
\hline Reserve Ratio & $\begin{array}{c}-0.26 \\
(1.08)\end{array}$ & $\begin{array}{l}-3.72^{* * *} \\
(0.95)\end{array}$ & $\begin{array}{l}-3.04^{* * *} \\
(0.89)\end{array}$ & $\begin{array}{l}-1.69 \\
(2.82)\end{array}$ & $\begin{array}{l}-1.29 \\
(1.11)\end{array}$ & $\begin{array}{c}-0.83 \\
(2.06)\end{array}$ \\
\hline Sovereign Debt & $\begin{array}{l}1.10 \\
(0.70)\end{array}$ & $\begin{array}{c}0.84 \\
(0.70)\end{array}$ & $\begin{array}{c}0.83 \\
(0.73)\end{array}$ & $\begin{array}{r}1.74^{*} \\
(0.89)\end{array}$ & $\begin{array}{l}1.75^{* *} \\
(0.88)\end{array}$ & $\begin{array}{l}1.76^{* *} \\
(0.88)\end{array}$ \\
\hline Private Debt & $\begin{array}{l}0.65 \\
(0.54)\end{array}$ & $\begin{array}{c}0.70 \\
(0.57)\end{array}$ & $\begin{array}{c}0.65 \\
(0.55)\end{array}$ & $\begin{array}{c}0.65 \\
(0.43)\end{array}$ & $\begin{array}{c}0.66 \\
(0.48)\end{array}$ & $\begin{array}{c}0.67 \\
(0.44)\end{array}$ \\
\hline $\begin{array}{l}\text { Remunerated } \\
\text { Domestic Liabilites }\end{array}$ & $\begin{array}{c}-4.27^{* *} \\
(1.67)\end{array}$ & & $\begin{array}{c}-1.15 \\
(0.89)\end{array}$ & $\begin{array}{c}0.40 \\
(3.36)\end{array}$ & & $\begin{array}{c}-0.49 \\
(2.58)\end{array}$ \\
\hline $\begin{array}{l}\text { Unsterilized } \\
\text { Purchases }\end{array}$ & $\begin{array}{r}-2.92^{*} \\
(1.61)\end{array}$ & $\begin{array}{c}0.55 \\
(1.18)\end{array}$ & & $\begin{array}{l}0.81 \\
(2.37)\end{array}$ & $\begin{array}{c}0.42 \\
(2.72)\end{array}$ & \\
\hline $\begin{array}{l}\text { Others } \\
\text { Balance Sheet }\end{array}$ & $\begin{array}{c}-2.69^{* *} \\
(1.07)\end{array}$ & $\begin{array}{c}1.34 \\
(0.94)\end{array}$ & $\begin{array}{c}0.58 \\
(0.72)\end{array}$ & $\begin{array}{l}2.12 \\
(2.93)\end{array}$ & $\begin{array}{c}1.69 \\
(1.32)\end{array}$ & $\begin{array}{l}1.21 \\
(2.44)\end{array}$ \\
\hline External Liabilities & & $\begin{array}{l}5.25^{* * *} \\
(1.31)\end{array}$ & $\begin{array}{l}4.55^{* * *} \\
(1.05)\end{array}$ & & $\begin{array}{c}-0.57 \\
(3.53)\end{array}$ & $\begin{array}{l}-1.01 \\
(2.15)\end{array}$ \\
\hline Observations & 2,683 & 2,683 & 2,683 & 1,814 & 1,814 & 1,814 \\
\hline Adjusted $\mathrm{R}^{2}$ & 0.67 & 0.67 & 0.68 & 0.64 & 0.64 & 0.64 \\
\hline
\end{tabular}

Note: Robust standard errors in parentheses. Risk Aversion, Rating and World rate are expressed in logs, the remaining variables are ratios of GDP. All regressions include year and country fixed effects. ${ }^{*} \mathrm{p}<0.1 ;{ }^{* *} \mathrm{p}<0.05 ;{ }^{* * *} \mathrm{p}<0.01$ 
Table C.5: Regression Results. Split Sample by Deficit

\begin{tabular}{|c|c|c|c|c|c|c|}
\hline & \multicolumn{6}{|c|}{ Dependent variable: } \\
\hline & \multicolumn{6}{|c|}{$\log ($ spread $)$} \\
\hline & \multicolumn{3}{|c|}{ With Deficit } & \multicolumn{3}{|c|}{ Without Deficit } \\
\hline & (1) & $(2)$ & $(3)$ & (4) & $(5)$ & (6) \\
\hline Risk Aversion & $\begin{array}{l}1.00^{* * *} \\
(0.05)\end{array}$ & $\begin{array}{l}1.02^{* * *} \\
(0.04)\end{array}$ & $\begin{array}{c}1.01^{* * *} \\
(0.04)\end{array}$ & $\begin{array}{c}0.87^{* * *} \\
(0.07)\end{array}$ & $\begin{array}{c}0.87^{* * *} \\
(0.07)\end{array}$ & $\begin{array}{c}0.87^{* * *} \\
(0.08)\end{array}$ \\
\hline Rating & $\begin{array}{c}-1.39^{* * *} \\
(0.22)\end{array}$ & $\begin{array}{c}-1.31^{* * *} \\
(0.28)\end{array}$ & $\begin{array}{c}-1.35^{* * *} \\
(0.24)\end{array}$ & $\begin{array}{c}-2.14^{* * *} \\
(0.54)\end{array}$ & $\begin{array}{c}-2.09^{* * *} \\
(0.54)\end{array}$ & $\begin{array}{r}-2.09^{* * *} \\
(0.51)\end{array}$ \\
\hline World Rate & $\begin{array}{l}0.13^{* *} \\
(0.07)\end{array}$ & $\begin{array}{l}0.14^{* *} \\
(0.07)\end{array}$ & $\begin{array}{l}0.14^{* *} \\
(0.07)\end{array}$ & $\begin{array}{c}0.20^{* * *} \\
(0.05)\end{array}$ & $\begin{array}{c}0.20^{* * *} \\
(0.06)\end{array}$ & $\begin{array}{c}0.20^{* * *} \\
(0.06)\end{array}$ \\
\hline Reserve Ratio & $\begin{array}{c}-2.36^{* * *} \\
(0.50)\end{array}$ & $\begin{array}{c}-7.37^{* * *} \\
(0.85)\end{array}$ & $\begin{array}{c}-4.49^{* * *} \\
(0.83)\end{array}$ & $\begin{array}{l}-0.61 \\
(1.94)\end{array}$ & $\begin{array}{c}-2.20^{* * *} \\
(0.83)\end{array}$ & $\begin{array}{l}-2.33 \\
(2.31)\end{array}$ \\
\hline Sovereign Debt & $\begin{array}{l}1.43^{* * *} \\
(0.47)\end{array}$ & $\begin{array}{l}0.89^{*} \\
(0.52)\end{array}$ & $\begin{array}{c}1.20^{* * *} \\
(0.46)\end{array}$ & $\begin{array}{l}2.30^{*} \\
(1.27)\end{array}$ & $\begin{array}{c}2.20 \\
(1.47)\end{array}$ & $\begin{array}{c}2.19 \\
(1.54)\end{array}$ \\
\hline Private Debt & $\begin{array}{c}0.57 \\
(0.35)\end{array}$ & $\begin{array}{l}0.82^{* *} \\
(0.34)\end{array}$ & $\begin{array}{c}0.66 \\
(0.46)\end{array}$ & $\begin{array}{l}-0.67 \\
(0.53)\end{array}$ & $\begin{array}{l}-0.78^{*} \\
(0.47)\end{array}$ & $\begin{array}{l}-0.78^{*} \\
(0.43)\end{array}$ \\
\hline $\begin{array}{l}\text { Remunerated } \\
\text { Domestic Liabilites }\end{array}$ & $\begin{array}{c}-6.19^{* * *} \\
(2.01)\end{array}$ & & $\begin{array}{c}-3.88^{* *} \\
(1.79)\end{array}$ & $\begin{array}{l}-1.63 \\
(2.04)\end{array}$ & & $\begin{array}{c}0.15 \\
(2.18)\end{array}$ \\
\hline $\begin{array}{l}\text { Unsterilized } \\
\text { Purchases }\end{array}$ & $\begin{array}{c}-2.03^{* *} \\
(1.01)\end{array}$ & $\begin{array}{l}2.73^{* *} \\
(1.09)\end{array}$ & & $\begin{array}{l}-1.76 \\
(1.84)\end{array}$ & $\begin{array}{l}-0.03 \\
(1.58)\end{array}$ & \\
\hline $\begin{array}{l}\text { Others } \\
\text { Balance Sheet }\end{array}$ & $\begin{array}{c}-2.54^{* * *} \\
(0.81)\end{array}$ & $\begin{array}{l}2.83^{* * *} \\
(0.84)\end{array}$ & $\begin{array}{l}-0.28 \\
(0.82)\end{array}$ & $\begin{array}{l}-0.85 \\
(2.31)\end{array}$ & $\begin{array}{l}1.08 \\
(0.85)\end{array}$ & $\begin{array}{l}1.22 \\
(2.84)\end{array}$ \\
\hline External Liabilities & & $\begin{array}{l}6.13^{* * *} \\
(1.26)\end{array}$ & $\begin{array}{l}2.69^{* *} \\
(1.12)\end{array}$ & & $\begin{array}{c}2.77 \\
(3.22)\end{array}$ & $\begin{array}{c}2.91 \\
(4.30)\end{array}$ \\
\hline Observations & 1,166 & 1,166 & 1,166 & 1,471 & 1,471 & 1,471 \\
\hline Adjusted $\mathrm{R}^{2}$ & 0.77 & 0.77 & 0.77 & 0.71 & 0.71 & 0.71 \\
\hline
\end{tabular}

Note: Robust standard errors in parentheses. Risk Aversion, Rating and World rate are expressed in logs, the remaining variables are ratios of GDP. All regressions include year and country fixed effects. ${ }^{*} \mathrm{p}<0.1 ;{ }^{* *} \mathrm{p}<0.05 ;{ }^{* * *} \mathrm{p}<0.01$. 
Table C.6: Regression Results. Split Sample by Dollarizated Countries

\begin{tabular}{|c|c|c|c|c|c|c|}
\hline & \multicolumn{6}{|c|}{ Dependent variable: } \\
\hline & \multicolumn{6}{|c|}{$\log$ (spread) } \\
\hline & \multicolumn{3}{|c|}{ Dollarizated } & \multicolumn{3}{|c|}{ Non-Dollarizated } \\
\hline & (1) & $(2)$ & (3) & (4) & (5) & (6) \\
\hline Risk Aversion & $\begin{array}{c}0.92^{* * *} \\
(0.06)\end{array}$ & $\begin{array}{c}0.92^{* * *} \\
(0.06)\end{array}$ & $\begin{array}{c}0.92^{* * *} \\
(0.06)\end{array}$ & $\begin{array}{c}0.95^{* * *} \\
(0.05)\end{array}$ & $\begin{array}{c}0.97^{* * *} \\
(0.05)\end{array}$ & $\begin{array}{c}0.97^{* * *} \\
(0.05)\end{array}$ \\
\hline Rating & $\begin{array}{c}-1.44^{* * *} \\
(0.53)\end{array}$ & $\begin{array}{c}-1.42^{* * *} \\
(0.52)\end{array}$ & $\begin{array}{c}-1.44^{* * *} \\
(0.53)\end{array}$ & $\begin{array}{c}-0.94^{* * *} \\
(0.19)\end{array}$ & $\begin{array}{c}-0.87^{* * *} \\
(0.16)\end{array}$ & $\begin{array}{c}-0.91^{* * *} \\
(0.15)\end{array}$ \\
\hline World Rate & $\begin{array}{c}0.07 \\
(0.06)\end{array}$ & $\begin{array}{c}0.07 \\
(0.06)\end{array}$ & $\begin{array}{c}0.07 \\
(0.06)\end{array}$ & $\begin{array}{c}0.28^{* * *} \\
(0.05)\end{array}$ & $\begin{array}{c}0.28^{* * *} \\
(0.05)\end{array}$ & $\begin{array}{c}0.28^{* * *} \\
(0.05)\end{array}$ \\
\hline Reserve Ratio & $\begin{array}{l}-0.41 \\
(0.78)\end{array}$ & $\begin{array}{c}-4.23^{* * *} \\
(1.06)\end{array}$ & $\begin{array}{c}-3.58^{* * *} \\
(1.26)\end{array}$ & $\begin{array}{l}-2.30^{*} \\
(1.23)\end{array}$ & $\begin{array}{c}-3.21^{* * *} \\
(0.60)\end{array}$ & $\begin{array}{l}-1.54 \\
(0.98)\end{array}$ \\
\hline Sovereign Debt & $\begin{array}{l}1.27^{*} \\
(0.70)\end{array}$ & $\begin{array}{l}1.08 \\
(0.71)\end{array}$ & $\begin{array}{l}1.10 \\
(0.69)\end{array}$ & $\begin{array}{l}1.36 \\
(0.97)\end{array}$ & $\begin{array}{l}1.34 \\
(0.94)\end{array}$ & $\begin{array}{l}1.12 \\
(0.91)\end{array}$ \\
\hline Private Debt & $\begin{array}{l}0.77^{* *} \\
(0.37)\end{array}$ & $\begin{array}{l}0.76^{* *} \\
(0.37)\end{array}$ & $\begin{array}{l}0.75^{* *} \\
(0.37)\end{array}$ & $\begin{array}{c}1.36 \\
(1.36)\end{array}$ & $\begin{array}{c}1.25 \\
(1.29)\end{array}$ & $\begin{array}{c}1.50 \\
(1.41)\end{array}$ \\
\hline $\begin{array}{l}\text { Remunerated } \\
\text { Domestic Liabilites }\end{array}$ & $\begin{array}{c}-3.89^{* * *} \\
(1.09)\end{array}$ & & $\begin{array}{l}-0.83 \\
(1.44)\end{array}$ & $\begin{array}{l}-1.22 \\
(1.04)\end{array}$ & & $\begin{array}{l}-1.61 \\
(1.12)\end{array}$ \\
\hline $\begin{array}{l}\text { Unsterilized } \\
\text { Purchases }\end{array}$ & $\begin{array}{c}-3.07^{* * *} \\
(0.72)\end{array}$ & $\begin{array}{c}0.54 \\
(1.24)\end{array}$ & & $\begin{array}{c}1.74 \\
(1.97)\end{array}$ & $\begin{array}{l}2.49^{*} \\
(1.43)\end{array}$ & \\
\hline $\begin{array}{l}\text { Others } \\
\text { Balance Sheet }\end{array}$ & $\begin{array}{c}-1.92^{* *} \\
(0.92)\end{array}$ & $\begin{array}{l}1.78^{* *} \\
(0.89)\end{array}$ & $\begin{array}{l}1.15 \\
(0.99)\end{array}$ & $\begin{array}{c}0.67 \\
(1.31)\end{array}$ & $\begin{array}{c}2.04^{* * *} \\
(0.77)\end{array}$ & $\begin{array}{c}0.09 \\
(1.00)\end{array}$ \\
\hline External Liabilities & & $\begin{array}{c}4.29^{* * *} \\
(1.10)\end{array}$ & $\begin{array}{c}3.60^{* * *} \\
(0.90)\end{array}$ & & $\begin{array}{c}6.48^{* * *} \\
(2.44)\end{array}$ & $\begin{array}{l}5.33^{* *} \\
(2.70)\end{array}$ \\
\hline Observations & 2,005 & 2,005 & 2,005 & 1,908 & 1,908 & 1,908 \\
\hline Adjusted $\mathrm{R}^{2}$ & 0.71 & 0.71 & 0.71 & 0.66 & 0.67 & 0.66 \\
\hline
\end{tabular}

Note: Robust standard errors in parentheses. Risk Aversion, Rating and World rate are expressed in logs, the remaining variables are ratios of GDP. All regressions include year and country fixed effects. ${ }^{*} \mathrm{p}<0.1 ;{ }^{* *} \mathrm{p}<0.05 ;{ }^{* * *} \mathrm{p}<0.01$. 
Table C.7: Regression Results. Split Sample by Country Debt

\begin{tabular}{|c|c|c|c|c|c|c|}
\hline & \multicolumn{6}{|c|}{ Dependent variable: } \\
\hline & \multicolumn{6}{|c|}{$\log ($ spread $)$} \\
\hline & \multicolumn{3}{|c|}{ High Debt } & \multicolumn{3}{|c|}{ Low Debt } \\
\hline & (1) & $(2)$ & (3) & (4) & (5) & (6) \\
\hline Risk Aversion & $\begin{array}{c}0.82^{* * *} \\
(0.12)\end{array}$ & $\begin{array}{c}0.83^{* * *} \\
(0.12)\end{array}$ & $\begin{array}{c}0.83^{* * *} \\
(0.12)\end{array}$ & $\begin{array}{l}1.00^{* * *} \\
(0.04)\end{array}$ & $\begin{array}{c}0.99^{* * *} \\
(0.04)\end{array}$ & $\begin{array}{c}1.00^{* * *} \\
(0.04)\end{array}$ \\
\hline Rating & $\begin{array}{c}-0.35^{* * *} \\
(0.06)\end{array}$ & $\begin{array}{c}-0.34^{* * *} \\
(0.05)\end{array}$ & $\begin{array}{c}-0.34^{* * *} \\
(0.05)\end{array}$ & $\begin{array}{c}-1.70^{* * *} \\
(0.34)\end{array}$ & $\begin{array}{c}-1.69^{* * *} \\
(0.35)\end{array}$ & $\begin{array}{r}-1.74^{* * *} \\
(0.36)\end{array}$ \\
\hline World Rate & $\begin{array}{l}0.23^{*} \\
(0.12)\end{array}$ & $\begin{array}{l}0.24^{*} \\
(0.12)\end{array}$ & $\begin{array}{l}0.23^{*} \\
(0.12)\end{array}$ & $\begin{array}{c}0.23^{* * *} \\
(0.05)\end{array}$ & $\begin{array}{c}0.23^{* * *} \\
(0.05)\end{array}$ & $\begin{array}{c}0.23^{* * *} \\
(0.05)\end{array}$ \\
\hline Reserve Ratio & $\begin{array}{l}-0.85 \\
(2.30)\end{array}$ & $\begin{array}{l}-4.41^{* * *} \\
(1.58)\end{array}$ & $\begin{array}{c}1.98^{* * *} \\
(0.55)\end{array}$ & $\begin{array}{l}-0.46 \\
(1.46)\end{array}$ & $\begin{array}{l}-2.03^{* *} \\
(0.96)\end{array}$ & $\begin{array}{c}0.29 \\
(1.38)\end{array}$ \\
\hline Sovereign Debt & $\begin{array}{l}-0.05 \\
(0.33)\end{array}$ & $\begin{array}{l}-0.06 \\
(0.34)\end{array}$ & $\begin{array}{l}-0.13 \\
(0.38)\end{array}$ & $\begin{array}{l}2.06^{* *} \\
(0.84)\end{array}$ & $\begin{array}{c}2.51^{* * *} \\
(0.79)\end{array}$ & $\begin{array}{c}2.25^{* * *} \\
(0.80)\end{array}$ \\
\hline Private Debt & $\begin{array}{c}0.33 \\
(0.31)\end{array}$ & $\begin{array}{c}0.33 \\
(0.32)\end{array}$ & $\begin{array}{c}0.30 \\
(0.33)\end{array}$ & $\begin{array}{c}0.34 \\
(0.59)\end{array}$ & $\begin{array}{c}0.31 \\
(0.63)\end{array}$ & $\begin{array}{c}0.28 \\
(0.59)\end{array}$ \\
\hline $\begin{array}{l}\text { Remunerated } \\
\text { Domestic Liabilites }\end{array}$ & $\begin{array}{l}-3.36 \\
(2.43)\end{array}$ & & $\begin{array}{c}-6.00^{* * *} \\
(1.84)\end{array}$ & $\begin{array}{l}-2.19 \\
(2.30)\end{array}$ & & $\begin{array}{l}-2.77 \\
(1.84)\end{array}$ \\
\hline $\begin{array}{l}\text { Unsterilized } \\
\text { Purchases }\end{array}$ & $\begin{array}{c}2.93 \\
(2.10)\end{array}$ & $\begin{array}{l}6.41^{* * *} \\
(1.80)\end{array}$ & & $\begin{array}{c}0.54 \\
(1.04)\end{array}$ & $\begin{array}{c}1.93 \\
(1.67)\end{array}$ & \\
\hline $\begin{array}{l}\text { Others } \\
\text { Balance Sheet }\end{array}$ & $\begin{array}{l}-0.85 \\
(2.70)\end{array}$ & $\begin{array}{c}2.66 \\
(1.77)\end{array}$ & $\begin{array}{c}-3.62^{* * *} \\
(0.84)\end{array}$ & $\begin{array}{c}0.14 \\
(1.88)\end{array}$ & $\begin{array}{l}1.75^{*} \\
(0.91)\end{array}$ & $\begin{array}{c}-0.64 \\
(1.68)\end{array}$ \\
\hline External Liabilities & & $\begin{array}{l}4.03^{*} \\
(2.14)\end{array}$ & $\begin{array}{l}-2.33 \\
(1.83)\end{array}$ & & $\begin{array}{c}0.56 \\
(2.16)\end{array}$ & $\begin{array}{l}-1.46 \\
(1.32)\end{array}$ \\
\hline Observations & 788 & 788 & 788 & 2,067 & 2,067 & 2,067 \\
\hline Adjusted $\mathrm{R}^{2}$ & 0.83 & 0.84 & 0.83 & 0.74 & 0.74 & 0.74 \\
\hline
\end{tabular}

Note: Robust standard errors in parentheses. Risk Aversion, Rating and World rate are expressed in $\operatorname{logs}$, the remaining variables are ratios of GDP. All regressions include year and country fixed effects. ${ }^{*} p<0.1 ;^{* *} p<0.05 ;^{* * *} p<0.01$. 


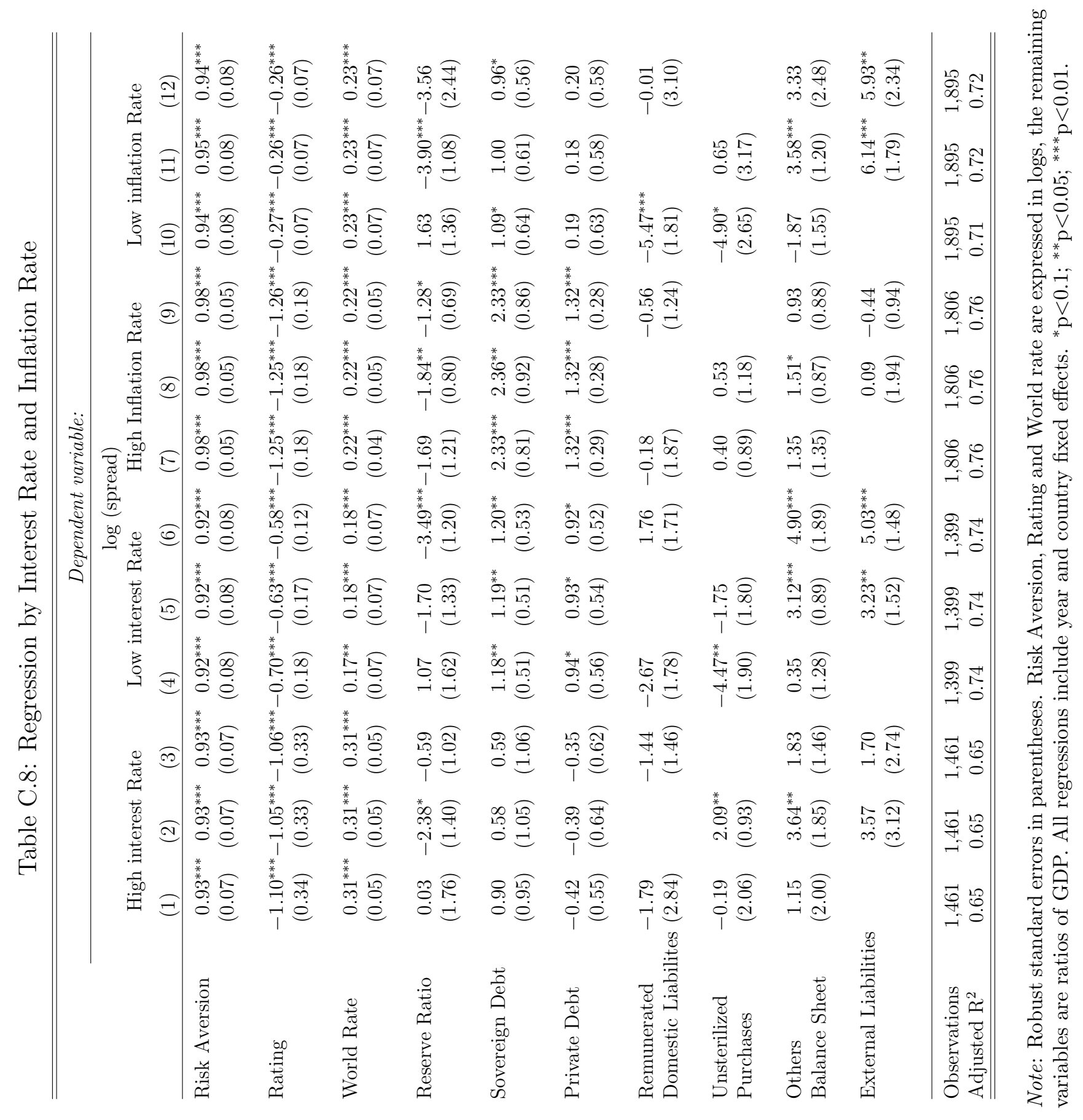


Table C.9: Results for Fiscal Balance and Dollarization samples

\begin{tabular}{|c|c|c|c|c|c|c|}
\hline & \multicolumn{6}{|c|}{ Dependent variable: } \\
\hline & \multicolumn{6}{|c|}{$\log ($ spread $)$} \\
\hline & \multicolumn{3}{|c|}{ Dollar sample } & \multicolumn{3}{|c|}{ Deficit sample } \\
\hline & (1) & (2) & (3) & (4) & (5) & (6) \\
\hline Risk Aversion & $\begin{array}{c}0.94^{* * *} \\
(0.04)\end{array}$ & $\begin{array}{c}0.95^{* * *} \\
(0.04)\end{array}$ & $\begin{array}{c}0.95^{* * *} \\
(0.04)\end{array}$ & $\begin{array}{l}0.93^{* * *} \\
(0.05)\end{array}$ & $\begin{array}{c}0.93^{* * *} \\
(0.05)\end{array}$ & $\begin{array}{l}0.93^{* * *} \\
(0.05)\end{array}$ \\
\hline Rating & $\begin{array}{c}-1.22^{* * *} \\
(0.23)\end{array}$ & $\begin{array}{c}-1.18^{* * *} \\
(0.24)\end{array}$ & $\begin{array}{c}-1.19^{* * *} \\
(0.25)\end{array}$ & $\begin{array}{c}-1.74^{* * *} \\
(0.46)\end{array}$ & $\begin{array}{c}-1.70^{* * *} \\
(0.49)\end{array}$ & $\begin{array}{c}-1.72^{* * *} \\
(0.51)\end{array}$ \\
\hline World Rate & $\begin{array}{c}0.18^{* * *} \\
(0.05)\end{array}$ & $\begin{array}{c}0.18^{* * *} \\
(0.05)\end{array}$ & $\begin{array}{c}0.18^{* * *} \\
(0.05)\end{array}$ & $\begin{array}{c}0.16^{* * *} \\
(0.05)\end{array}$ & $\begin{array}{c}0.17^{* * *} \\
(0.05)\end{array}$ & $\begin{array}{l}0.17^{* * *} \\
(0.05)\end{array}$ \\
\hline Reserve Ratio & $\begin{array}{l}-0.84 \\
(0.70)\end{array}$ & $\begin{array}{c}-3.01^{* * *} \\
(0.38)\end{array}$ & $\begin{array}{c}-2.47^{* * *} \\
(0.82)\end{array}$ & $\begin{array}{l}-0.75 \\
(0.67)\end{array}$ & $\begin{array}{l}-3.48^{* * *} \\
(0.97)\end{array}$ & $\begin{array}{c}-3.50^{* * *} \\
(1.04)\end{array}$ \\
\hline Sovereign Debt & $\begin{array}{l}1.18^{* *} \\
(0.56)\end{array}$ & $\begin{array}{l}1.07^{* *} \\
(0.54)\end{array}$ & $\begin{array}{l}1.07^{* *} \\
(0.54)\end{array}$ & $\begin{array}{l}1.20^{* *} \\
(0.54)\end{array}$ & $\begin{array}{l}1.07^{*} \\
(0.61)\end{array}$ & $\begin{array}{l}1.06^{*} \\
(0.62)\end{array}$ \\
\hline Private Debt & $\begin{array}{l}0.78^{* *} \\
(0.36)\end{array}$ & $\begin{array}{l}0.76^{* *} \\
(0.36)\end{array}$ & $\begin{array}{l}0.75^{* *} \\
(0.34)\end{array}$ & $\begin{array}{l}1.05^{* *} \\
(0.53)\end{array}$ & $\begin{array}{l}1.08^{*} \\
(0.57)\end{array}$ & $\begin{array}{l}1.01^{*} \\
(0.59)\end{array}$ \\
\hline $\begin{array}{l}\text { Remunerated } \\
\text { Domestic Liabilites }\end{array}$ & $\begin{array}{c}-2.59^{* * *} \\
(0.97)\end{array}$ & & $\begin{array}{l}-0.81 \\
(0.96)\end{array}$ & $\begin{array}{l}-2.97^{* * *} \\
(1.12)\end{array}$ & & $\begin{array}{l}-0.29 \\
(1.41)\end{array}$ \\
\hline $\begin{array}{l}\text { Unsterilized } \\
\text { Purchases }\end{array}$ & $\begin{array}{l}-1.63^{*} \\
(0.98)\end{array}$ & $\begin{array}{c}0.49 \\
(0.98)\end{array}$ & & $\begin{array}{c}-2.89^{* * *} \\
(0.82)\end{array}$ & $\begin{array}{l}-0.27 \\
(1.15)\end{array}$ & \\
\hline $\begin{array}{l}\text { Others } \\
\text { Balance Sheet }\end{array}$ & $\begin{array}{l}-1.21^{*} \\
(0.73)\end{array}$ & $\begin{array}{l}1.25^{* *} \\
(0.50)\end{array}$ & $\begin{array}{c}0.66 \\
(0.89)\end{array}$ & $\begin{array}{l}-1.51^{*} \\
(0.85)\end{array}$ & $\begin{array}{l}1.41^{*} \\
(0.79)\end{array}$ & $\begin{array}{c}1.45 \\
(0.95)\end{array}$ \\
\hline External Liabilities & & $\begin{array}{r}3.21^{* * *} \\
(0.93)\end{array}$ & $\begin{array}{l}2.63^{* * *} \\
(0.74)\end{array}$ & & $\begin{array}{l}3.21^{* *} \\
(1.35)\end{array}$ & $\begin{array}{l}3.23^{* *} \\
(1.37)\end{array}$ \\
\hline Observations & 3,913 & 3,913 & 3,913 & 2,637 & 2,637 & 2,637 \\
\hline Adjusted $\mathrm{R}^{2}$ & 0.66 & 0.66 & 0.66 & 0.67 & 0.67 & 0.67 \\
\hline
\end{tabular}

Note: Robust standard errors in parentheses. Risk Aversion, Rating and World rate are expressed in logs, the remaining variables are ratios of GDP. All regressions include year and country fixed effects. ${ }^{*} \mathrm{p}<0.1 ;{ }^{* *} \mathrm{p}<0.05 ;{ }^{* *} \mathrm{p}<0.01$. 
Table C.10: Regression results. Exogenous shocks without outlier.

\begin{tabular}{|c|c|c|c|}
\hline & \multicolumn{3}{|c|}{ Dependent variable: Spread Variation } \\
\hline & Domestic Liabilities & External Liabilities & $\mathrm{p}$-value difference \\
\hline Pooled & $\begin{array}{c}-27.60^{* *} \\
(13.10)\end{array}$ & $\begin{array}{c}53.40 \\
(34.90)\end{array}$ & $0.03^{* *}$ \\
\hline First Event & $\begin{array}{c}-37.60^{* * *} \\
(9.70)\end{array}$ & $\begin{array}{c}45.10 \\
(28.00)\end{array}$ & $0.00^{* * *}$ \\
\hline Second Event & $\begin{array}{c}-58.00^{* *} \\
(27.40)\end{array}$ & $\begin{array}{c}208.00^{* * *} \\
(37.30)\end{array}$ & $0.00^{* * *}$ \\
\hline Third Event & $\begin{array}{c}8.02 \\
(16.20)\end{array}$ & $\begin{array}{c}-11.10^{* *} \\
(4.97)\end{array}$ & 0.26 \\
\hline
\end{tabular}

Note: Robust standard errors in parentheses. ${ }^{*} \mathrm{p}<0.1 ;{ }^{* *} \mathrm{p}<0.05 ;{ }^{* * *} \mathrm{p}<0.01$ 
Table C.11: Adding the currency composition of private debt

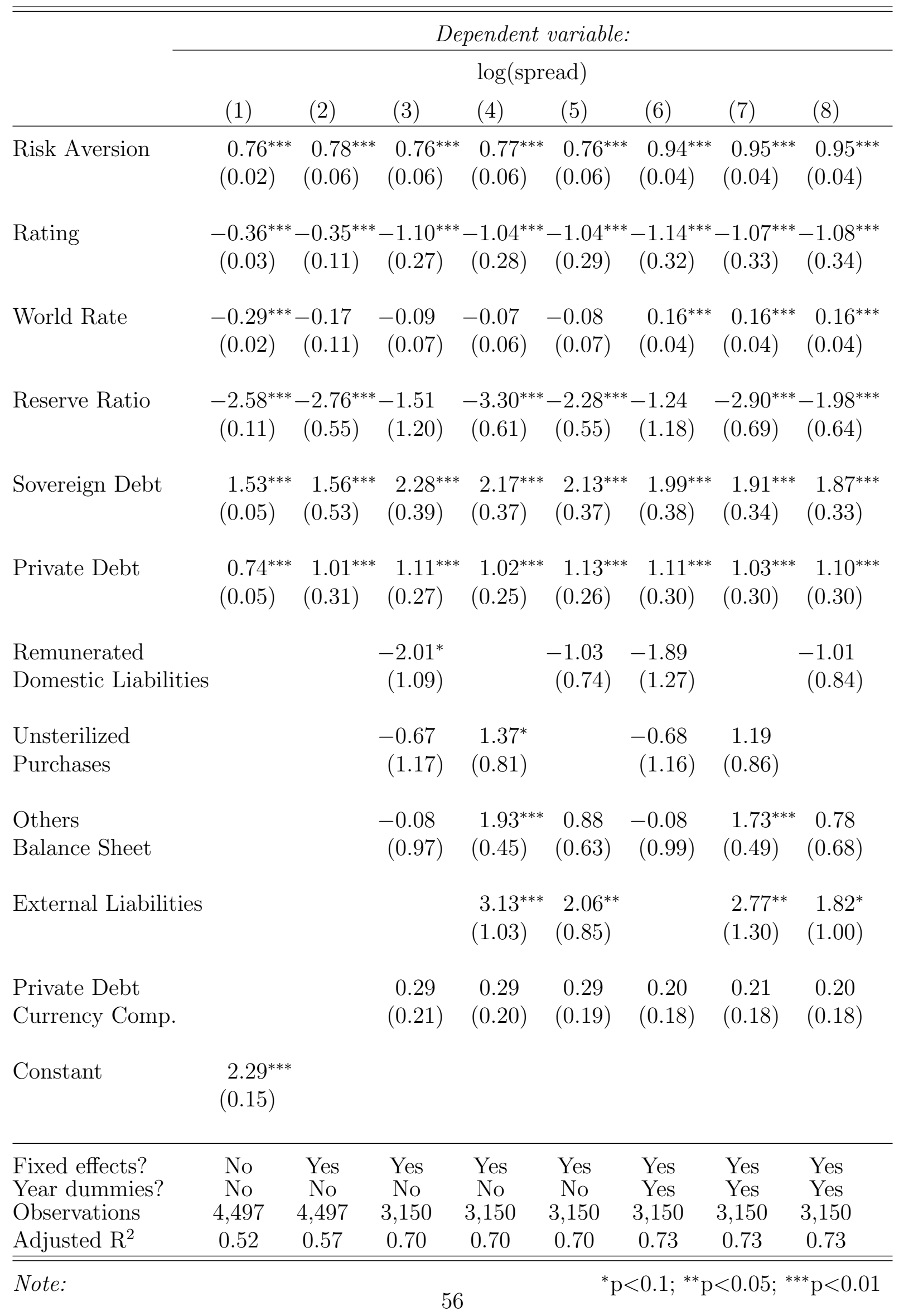

